\title{
ASSURE Öğretim Tasarım Modeline Dayalı Ders Tasarımının İlkokul İkinci Sınıfta Zihinden Toplama İşlemindeki Başarıya Etkisi
}

\author{
DOI: 10.26466/opus.846504
}

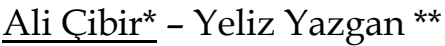 \\ * Dr. Öğr. ,Bursa Uludağ Üniversitesi/Eğitim Bilimleri Ens., Bursa/Türkiye \\ E-Posta: alicibir43@gmail.com \\ ORCID: $\quad 0000-0002-5439-1436$ \\ ** Doç. Dr. Bursa Uludağ Üniversitesi, Temel Eğitim Bölümü, Bursa/Türkiye \\ E-Posta: yazgany@uludag.edu.tr \\ ORCID: $\underline{0000-0002-8417-1100}$
}

$\ddot{O} z$

Bu araştırmada, ASSURE Öğretim Tasarım Modeli ile ilkokul ikinci sımıfta "Zihinden Toplama İşlemi" konusuna yönelik ders tasarımı geliştirilmiş, geliştirilen bu ders tasarımının öğrencilerin "Zihinden Toplama İşlemi" konusundaki başarısına etkisi incelenmiştir. Bu amaçla öğrencilerin zihinden toplama işlemi yaparken onluk ve birlikleri ayırma, parça-bütün ilişkisi, en yakın onluğa yuvarlama, üzerine saymaya yönelik başarılarına bakılmıştır. Ayrıca ders tasarımının zihinden toplama işlemine ait kazanımları gerçekleştirme yönünden farklılık oluşturup oluşturmadığına bakılmıştır. Araştırmada nicel ve nitel verilerin birlikte çalışıldığı yakınsayan paralel desen tercih edilmiştir. Çalışma, Kütahya ili Merkez ilçedeki bir ilkokulun 2-B (kontrol grubu/n=20) ve 2-D (deney grubu/n=21) sinfflarında öğrenim görmekte olan toplam 41 öğrenci ile gerçekleştirilmiştir. Nicel ve nitel verilerin toplamasında birinci araştırmacı tarafından geliştirilen başarı testi ve görüşme formu kullanılmıştır. Araştırmanın sonucunda, ASSURE Öğretim Tasarım Modeli ile tasarlanan öğretimin öğrencilerin zihinden toplama işlemindeki başarıların olumlu yönde etkilediği sonucuna ulaşılmıştır. Ayrıca ASSURE Öğretim Tasarım Modeli ile planlanan dersin öğrencilerin onluk ve birlikleri ayırma, parça-bütün ilişkisi kurma, en yakın onluğa yuvarlama ve üzerine saymada etkili olduğu sonucuna ulaşılmıştır. Zihinden toplam işlemi kazanımlarına yönelik öğrencilerin en fazla onluk ve birlikleri ayırma ve en yakın onluğa yuvarlama stratejilerini tercih ettikleri yapılan görüşmeler neticesinde tespit edilmiştir.

Anahtar Kelimeler: ASSURE Öğretim Tasartm Modeli, 7E öğretim modeli, tahmin etme, zihinden toplama işlemi, zihinden toplama tablosu. 


\title{
The Effect of The Course Design Based on ASSURE Instructional Design Model on Success in Mental Addition in the Second Grade
}

\begin{abstract}
In this study, a lesson design was developed based on the ASSURE Instructional Design Model for "Mental Addition" at the second-grade level, and the effect of the developed lesson design on success of students was investigated. For this purpose, the students' success in separating tens and units, partwhole relationship, rounding to the nearest tens, and counting were examined while doing the mental calculation. In addition, it was examined whether the lesson design made a difference in terms of achieving the acquisitions of mental addition. The mixed-method in which quantitative and qualitative data were studied together was preferred in the study. The convergent parallel design was used as a mixed research design. The study was carried out with 41 students attending 2-B (control group/ $n=20$ ) and 2-D (experimental group $/ n=21$ ) classes of a primary school in a central town of Kütahya. An achievement test and an interview form developed by the first researcher were used in the collection of quantitative and qualitative data. As a result of the research, it was concluded that the instruction designed based on ASSURE Instructional Design Model has positively affected the students' success in mental addition.
\end{abstract}

Keywords: ASSURE instructional design model, 7E instruction model, estimation, mental addition, mental addition table. 


\section{Giriş}

Günümüzde öğrenciler arasındaki bireysel farklılıklardan kaynaklanan öğrenme sorunları, değişen öğrenme-öğretme yaklaşımları ve teknolojinin eğitime daha çok dâhil olması ile birlikte giderek daha fazla önem kazanmaktadır. Her bir öğrencinin ilgi, istek ve öğrenme stillerinin farklı olduğu için, ders planlama sürecinin de bu ihtiyaçlara mümkün olduğu kadar cevap verecek şekilde yapılandırılması gerekmektedir. Çünkü bu planlama sürecinde yaşanılabilecek aksaklıklar öğrenme kabiliyeti farklı olan öğrenciler arasında öğrenme sorunlarına neden olmaktadır. Bu sorunlar, bazı öğrencilerin bilgileri edinememelerine ya da eksik edinmelerine neden olmaktadır. Bu nedenle, bu sorunların oluşmaması için ders planlamasının tesadüflere bırakılmaması, dikkatlice ve eksiksiz planlanması önem arz etmektedir. Amaçlanan öğrenme-öğretme hedeflerine ulaşılabilmesi için öğrencilerin öğrenme stilleri ile birlikte belirlenen konu ya da kazanımlara uygun öğretim modeli, strateji, yöntem ve tekniklerin kullanılması da gereklidir. Böylelikle öğrencilerin hedeflenen bilgileri/kazanımları istenilen düzeyde öğrenebilmesi ve en üst düzeyde öğrenmelerin gerçekleşebilmesi sağlanabilir.

Matematik hem okul hayatı boyunca hem de okul dışında gerekli ve önemli bir derstir. Sayma ve işlem yapma gibi sayısal beceriler de temel öğrenme ihtiyaçları arasındadır. Bu beceriler okul öncesi dönemden itibaren öğrenilmesi gerekmektedir. Dolayısıyla, çocukların sayma etkinlikleri erken çocukluk döneminde başlamaktadır. Bu dönemde, çocuklar sayı kavramı hakkında fikir sahibi olmaya başlarlar ve başlangıçta anlamsız olan sayılara belli bir süre sonra anlam yüklenmeye başlarlar. Bu anlamlandırmayı çocuğun kendisinin oluşturması gerekmektedir (Van de Walle, Karp, ve Bay-Williams, 2016, s.127). Çünkü matematik erken çocukluk dönemindeki çocukların dünyayı anlamasının ve anlamlandırmasının bir yoludur. Bu nedenle, bu dönemden itibaren çocuğa oyun ve günlük etkileşimler yoluyla fırsatlar sunularak matematik gelişiminin temelleri atılır. Bu temeller atılırken, çocukların matematiğe karşı olumlu tutum geliştirmeleri için teşvik edilmesi de önemlidir. Çünkü matematiğe yönelik tutum, matematiğin her yerde olduğunu gözlemlemeyi, matematiği ilginç ve eğlenceli olarak tanımlamayı ve matematiğin yapılabilecek bir şey olduğuna inandırmayı içerir (Buttler, 2019). Böylelikle, bireylerde var olan sayı bilgisi daha sağlıklı biçimde gelişebilir ve bireylerin özellikle de sayıları daha esnek ve akıcı bir şekilde kullanabilmesinin yolu 
açılmış olur. Sayı hissi gelişmiş olan çocukların muhakeme gücü de yüksek olur ve bu kapsamda tahmin ve zihinden hesap yapma becerilerini doğru ve eksiksiz biçimde kullanabilmeleri (Whitin, 1994, s.21) sayesinde problem çözme becerileri de gelişir (Olkun, Altun, Göçer Şahin, Akkurt Denizli, 2015).

Matematik dersi öğretim programında öğrencilerin matematik okuryazarı olmaları, öğrendiklerini günlük hayatta kullanabilmesini amaçlanmıştır. $\mathrm{Bu}$ amaçların tamamlayıcısı olarak tahmin ve zihinden toplama becerilerini etkin bir şekilde kullanabilmeleri beklenmektedir. Zihinden işlem yapma programin ana hedeflerinden biridir (MEB, 2018). Programda ise en fazla say1 hissi ile ilgili kazanım \%22 ile 2. Sınıf düzeyindedir (Çetin ve Öztürk, 2020). Zihinden ve tahmini hesap, günlük yaşantıda hesap makinesi, bilgisayar veya yazılı hesaptan daha fazla kullanılmaktadır. Bireyler günlük hayatta gerek mesafeyi hesaplarken gerek alışveriş yaparken kâğıt kalem kullanmak yerine sayıların özelliklerinden yaralanarak sonuca ulaşmayı tercih ederler (Çekirdekçi, 2005). Yani, zihinden hesaplar günlük yaşantı ile iç içedir. Özellikle hiç okula gitmeyen matematik eğitimi almayan bireylerde zihinden işlemleri kullanırlar. Onların zihinden hesaplarını gelişmesinde alış-veriş işlemleri gibi günlük hayatta karşılaşmış oldukları problemler etkili olmuştur. Kişiler günlük hayatta matematiği ilgilendiren durumlar ile baş başa kaldıklarında insan zihni en kısa yoldan sonuca ulaşabilmek için formel eğitimden farklı veya kısmen bağımlı stratejiler geliştirir (Çavuş Erdem ve Duran, 2015).

Her bir öğrencinin kendi öğrenmesini yapılandırabilmesi için öğrenmeyi hayatının bir parçası haline getirebilmesi ve deneyimleri ile öğrenmeyi keşfedebilmesi gereklidir (Karakış, 2014). Öğretmen de öğrencilerin gelişim dönemlerini dikkate alarak, ilkokul düzeyinde somut işlemler döneminin gerektirdiği gelişimsel ödevleri öğrencilere vermelidir. Bu kapsamda, matematik öğrencilere sevdikleri ve ilgilerini çeken etkinlikler ile kazandırılabilir. Bu da oyunlar ya da öğrencilerin vakit geçirmekten hoşlandıkları teknoloji destekli öğretim yöntemleri vasıtasıyla kolaylıkla gerçekleştirilebilir. Geleneksel öğretimin aksine, öğretmenin rolü öğrencinin bilgisini yapılandırabilmesi için gerekli ortam ve malzemeyi öğrenciye sağlamasıdır. Öğrenciler öğretmen rehberliğinde aktif olarak kendi öğrenmelerini inşa ederken matematikten de zevk alabilirler (Yiğit, 2007). Bu kapsamda öğretmen, öğretimi öğrencinin ön bilgilerini yoklayarak, öğrenme stiline uygun düzenlemelidir (Karakış, 2014). Öğretmenler öğretimlerinde Yapılandırmacı Öğrenme yaklaşı- 
mına da uygun olarak Buluş Stratejisi, Araştırma-İnceleme, İşbirlikçi Öğrenme, Drama, Proje Temelli Öğrenme, Problem Çözme Tabanlı Öğrenme, Aktif Öğrenme, Teknoloji Destekli Öğrenme, 5E ve 7E gibi yöntem ve teknikleri kullanabilirken (Ateş, 2017; Şentürk, 2010); ASSURE, ADDIE ve Dick and Carey gibi farklı öğretim tasarım modellerinden uygun olanları tercih edilebilirler.

Öğrenme teorileri bireylerin öğrenmelerinin nasıl gerçekleştiği, yeteneklerinin nasıl ortaya çıktı̆̆ ile ilgilenirken, öğretim tasarım modelleri de planlanmış bir derste öğretimin nasıl gerçekleşebileceği ile ilgilenmektedir (Esmer, 2018). Türkiye'de yapılan farklı çalışmalarda (Uysal ve Gürcan, 2004; Karakış, 2014; Ocak, 2015; Keleş, Fiş Erümit, Özkale ve Aksoy, 2016; Akay, 2017; Bayezit, 2019) birçok öğretim tasarım modellerinin açılandığı ve kullanıldığ1 görülmüştür. Bu öğretim tasarım modellerinden biri olan ASSURE Öğretim Tasarım Modeli (ÖTM) diğer modellere kıyasla daha mikro ölçekli bir öğretim modelidir. Tasarım modelleri çoğunlukla daha kapsamlı olduğu için bir ekiple yürütülürken, ASSURE ÖTM ise günlük bir ders için bir eğitimci tarafından farklı teknolojiler kullanılarak yapılabilmektedir (Karakış, 2014). ASSURE ÖTM ile hazırlanan öğretim programları öğrencilerin istenilen hedeflere varabilmesi için daha etkili, verimli ve çekici olmaktadır. Böylelikle, öğrencilerin bireysel özellikleri dikkate alınarak istenilen öğrenme hedeflerine ulaşabilmek için en uygun medya ve materyaller kullanılarak öğrencilerin aktif katılımı ile üst düzey öğrenme gerçekleştirilebilir (Uysal ve Gürcan, 2004). Matematik dersini planlama ve uygulama, öğrencilerin ilgi, istek ve ihtiyaçları da göz önüne alınarak ve sevebilecekleri şekilde yapılmalıdır. Özellikle de öğrencilerin ilgisini çekebilmek, onların kendi öğrenmelerini aktif olarak yapılandırabilmek için teknoloji destekli öğretim tekniklerinin kullanımı önemlidir ve giderek artmaktadır. Teknoloji destekli öğretim programının istenilen hedeflere ulaşabilmesi için planlı bir şekilde öğretim sürecinin tasarlanması gerekmektedir. ASSURE ÖTM'de matematik ve teknolojinin bir arada iyi biçimde uygulandığı tasarımlara imkân vermektedir.

ASSURE ÖTM altı aşamadan oluşmaktadır (Karakış, 2014). Bunlar; öğrencilerin analizi (analyze learners), hedeflerin belirlenmesi (state objectives), medya ve materyal seçimi (select media and materials), medya ve materyallerin kullanımı (utilize media and materials), öğrenen katılımı (require learner participation), değerlendirme ve düzeltme (Evaluate and revise) dir (Heinrich, Molenda ve Russel, 1993; Akt. Ocak, 2015, s.86). Bu öğretim tasarım 
modelinin basamaklarına göre öğrenme materyalinin nasıl geliştirildiği aşağıdaki gibi açılanabilir (Ocak, 2015, s.86):

Öğrenenlerin Analizi: ASSURE Modeli'nin ilk basamağı olan bu adım, öğrencilerin genel özellikleri (sınıf, yaş, etnik grup, cinsiyet ve var olan zihinsel, sosyal veya fiziksel problemler, ekonomik durumlar, kültürel ve duygusal konular, deneyimleri vb.), giriş özellikleri (ön bilgi ve beceriler, tutum vb.) ve öğrenme stillerinden (sözel, metinsel, mantıksal, görsel, müziksel, yapılandırılmış vb.) oluşmaktadır.

Öğrenme Hedeflerinin Belirlenmesi: Analiz aşamasında, öğrenme amaç ve hedeflerinin kesin bir şekilde belirlenmesi gerekmektedir. Amaçların yazılması aşamasında hedef kitle, gösterilmesi istenilen davranış, davranışın hangi şartlar altında gözlemleneceği ve öğrenilen becerilerin hangi standartlarda olacağı göz önünde bulundurulmalıdır. Öğrencilerin neler yapacağı, hangi davranışların beklendiğine dair hedeflerin oluşturulması, öğrenmenin nasıl değerlendirileceği, kullanılması gereken yöntem ve teknikler ayrıntılı bir şekilde belirtilmelidir.

Medya ve Kullanılacak Materyallerin Seçilmesi veya Üretilmesi: Öğrenci özellikleri ve hedefler belirlendikten sonra, öğrencilerin öğrenmelerine yardımcı olacak en uygun materyal veya medya araçlarının seçilmesi gerekmektedir. Kullanılacak medya; yazı, resim, video, ses ve bilgisayar çoklu ortamları olabilir. Materyaller ise özel yazılım programları, video kasetler, resimler, bilgisayar ve yazıcı gibi aygitlar olabilir.

Seçilen Medya ve Materyallerin Kullanilmasi: Kullanılacak medya ve materyallerin seçilmesinin ardından bu medya ve materyallerin kullanılması aşamasına geçilir. $\mathrm{Bu}$ aşamada medya ve materyaller gözden geçirilmeli, ön hazırlıklar yapılmalıdır. Elektronik medya ve materyaller seçilecekse ön denemeler de yapılmalıdır.

Öğrenenlerin Katılımını Sağlama: Bu aşama, öğrenme ortamlarının öğrenciye sunulduğu aşamadır. Özellikle de oluşturulan medya ve materyallerin kullanımında öğrencinin aktif olarak katılması sağlanmalıdır. Öğrenci medya ve materyaller aracılığı ile kendi öğrenmesini inşa etmelidir. Öğrenme ortamlarında kullanılacak yöntem ve teknikler, bu aşamada öğrencilerin eleştirel düşünme becerilerini en üst seviyeye çıaracak şekilde planlanmalıdır. 
Değerlendirme ve Revize Etme: Kullanılan medya ve materyallerin öğrenmeyi ne tür etkilediğinin anlaşılması için değerlendirme yapılır. Değerlendirme sonucuna göre medya ve materyaller ile ilgili herhangi bir sorun olup olmadığına bakılır ve bir sorun varsa revize edilir.

Literatürde ASSURE ÖTM'ni ve uygulamalarını içeren farklı çalışmalara (Baran, 2010; Eren, Aktürk, Demirer ve Şahin, 2010; Özdemir ve Uyangör, 2011; Göksu, Özcan, Çakır ve Göktaş, 2014; Karakış, 2014; Çetinkaya ve Taş, 2016; Karaduman, Sezgin Memnun ve Çakır. 2019; Gündüzalp ve Yıldız 2020) rastlanmıştır. Baran (2010), ASSURE ÖTM'nin bir yol haritası olarak kullanıldığı çalışmasında, interaktif akıllı tahta ile ders tasarım sürecindeki deneyimleri incelemiştir. Çalışmanın sonuçları, ASSURE ÖTM'nin öğrencilerin interaktif tahtayı öğrenme süreçlerine olumlu katkı sağladığını göstermiştir. Eren ve diğerleri (2010), altıncı sınıf bilişim teknolojileri dersi "Hesaplama Yapryorum" ünitesi ile ilgili ASSURE ÖTM'ye uygun bir ders materyali hazırlamışlardır. Araştırma sonucunda ise ASSURE ÖTM ile hazırlanan bir materyalin öğrencilerin akademik başarısına, tutum ve öz yeterliklerine olumlu etkisinin olduğu görülmüştür. Özdemir ve Uyangör (2011) ASSURE ÖTM'yi temele alarak ve bu modellerini Dick ve Carey Modeli ile destekleyerek yeni bir öğretim tasarım modeli oluşturmuşlardır. Sonuç olarak tasarlanan öğretim tasarım modelinin basamaklarının ve alt düzeylerinin eğitime uygun olacağı düşünülmektedir. Göksu ve diğerleri (2014) Türkiye'de eğitimde yapılan araştırmalarda kullanılan öğretim tasarımı modellerini incelemiştir. Bu incelemelere göre ise ASSURE ÖTM'nin en fazla kullanılan modellerden birisi olduğu sonucuna varılmıştır. Karakış (2014) ASSURE ÖTM ve ARCS Motivasyon Model'ine göre geliştirilen bir öğretim materyali aracilığı ile öğrencilerin teknoloji destekli öğretim ve matematik dersine yönelik tutum ve başarısını incelemiştir. Geliştirilen yazılımın öğrencilerin matematik başarılarını artırdığı, matematiğe ve teknoloji destekli öğretime yönelik olumlu tutumlarını artırdığı sonucuna varılmıştır. Çetinkaya ve Taş (2016)'e göre ASSURE ÖTM'yi kullanarak altınc sınıf "Vücudumuzda Sistemler" ünitesine yönelik Web materyali geliştirmişler ve bu materyal ile öğrencilerin öğrenme güçlüklerinin giderilmesini hedeflemişlerdir. Hazırlanan materyal ile öğrencilerin kazanımları kazanıp kazanamadıkları tespit edilip, öğrenme düzeyleri hakkında bilgi elde edilmiştir. Karaduman, Sezgin Memnun ve Çakır (2019) ASSURE ÖTM ile olasılık kavramının öğretimini araştırmıştır, uygulanan tasarım öğrencilerin olasılık konusundaki başarılarını olumlu yönde etkilemiştir. 
Gündüzalp ve Yıldız (2020) ise ASSURE ÖTM ile tasarlanmış bilgi ve iletişim teknolojileri dersinin öğrencilerin bilgisayar kaygıları, bilgi ve iletişim teknolojileri kullanımıma yönelik tutumları ve öğrenci görüşleri üzerindeki etkilerini belirlemeye çalışmışlardır. ASSURE ÖTM ile tasarlanan derste öğrencilerin bilgisayar derslerine yönelik olumlu tutumlarının arttı̆̆, kaygilarının azaldığı, derse karşı motive oldukları tespit edilmiştir. Buradan, ASSURE ÖTM ile ilgili olarak yapılan bu çalışmaların Matematik ve Fen Bilgisi derslerinde yoğunlaştı̆̆ı, genellikle de teknoloji destekli öğretim modelleri ile desteklendiği görülmektedir. Bu çalışmada, yapılan bu çalışmalardan farklı olarak ilkokul ikinci sınıf matematik dersi "Toplama İşlemi” alt öğrenme alanındaki, "Zihinden toplama işlemi yapar." kazanımına yönelik ASSURE ÖTM ile teknoloji destekli bir program üzerinden geliştirilen öğretim tasarımının öğrencilerin öğrenmelerine etkisi incelenmiştir. Ayrıca, bu çalışmada "karma yöntem" kullanılmış olup deneysel bir çalışma gerçekleştirilmiştir. Araştırmanın bu yönüyle de önemli olduğu ve alana katkı sağlayacağı düşünülmektedir.

\section{Çalışmanın Amacı}

Bu çalışmada, ASSURE Öğretim Tasarım Modeli ile teknoloji destekli bir programdan da yararlanılarak ikinci sinıf matematik dersi "Zihinden toplama işlemi yapar." kazanımına yönelik geliştirilen öğretim tasarımının öğrencilerin başarılarına etkisinin incelenmesi amaçlanmıştır. Bu amaçla, aşağıda yer alan araştırma problemlerine cevap aranmıştır:

- İlkokul ikinci sınıfta ASSURE Öğretim Tasarım Modeli aracılı̆̆g ile geliştirilen öğretim tasarımı, öğrencilerin "Zihinden Toplama İşlemi" ndeki başarıları açısından istatistiksel olarak anlamlı düzeyde farklılık oluşturmakta midir?

- İlkokul ikinci sınıfta ASSURE Öğretim Tasarım Modeli aracılı̆̆g ile geliştirilen öğretim tasarımı, öğrencilerin "Zihinden Toplama İşlemi" faktörleri (Onluk ve birliklere ayırma, parça-bütün ilişkisi kurma, sayıları en yakın onluğa yuvarlayabilme, üzerine sayma yapma) açısından istatistiksel olarak anlamlı düzeyde farklılık oluşturmakta mıdır?

- İlkokul ikinci sınıfta ASSURE Öğretim Tasarım Modeli aracılı̆̆ı ile geliştirilen öğretim tasarımı, öğrencilerin "Zihinden Toplama İşlemi" ne ait 
kazanımları gerçekleştirebilmeleri açısından farklılık oluşturmakta mıdir?

\section{Yöntem}

Bu bölümde; ASSURE Öğretim Tasarım Modeli aracılığı ile geliştirilen öğretim tasarımının ikinci sınıf öğrencilerinin "Zihinden Toplama İşlemi" ndeki başarıları etkisinin inceleneceği bu araştırmanın modeline, çalışma gruplarına, veri toplamaya ilişkin bilgilere, nicel ve nitel analizlere ait detaylı bilgilere yer verilmiştir.

\section{Araştırma Modeli}

Bu çalışmada nitel ve nicel verilerin bir arada kullanıldığı yakınsayan paralel desen kullanılmıştır. Yakınsayan paralel desen hem nitel hem nicel verilerin aynı aşamada test edildiği bunların neticesinde üçüncü bir yol olarak tek bir yorum ile birleştirildiği bir desendir. Ayrıca bu desende bir olgunun daha iyi açıklanması için nitel ve nicel bulgular tamamlayıcı şekilde sentezlenir, nicel bulgular nitel bulgular ile açıklanır (Creswell ve Plano Clark, 2020, s.85). Karma yöntem seçilmesi ile nitel ve nicel verilerin birleştirilmesi, birbirleri ile karşılaştırılması ve her iki veri türü ile elde edilen bilgilerin doğruluğunun güçlendirilmesi sağlanmaktadır (Alkan, Şimşek ve Armağan Erbil, 2019). Bu çalışmada ASSURE ÖTM'yi öğrencilerin zihinden toplamadaki başarısına etkisi incelendiğinden, çalışma "Ön-Son Test Kontrol Gruplu Deneysel Desen" de yapılmıştır. Bu kapsamda, nicel veriler ön ve son test olarak yapılan uygulamalardan, nitel veriler ise öğrencilerle yapılan görüşmelerden sağlanmıştır. Bu çalışma kapsamına alınan iki sınıftan birinde öğrenim görmekte olup çalışmaya katılma konusunda gönüllü öğrenciler deney grubunu, diğer sınıfta öğrenim görmekte olan gönüllü öğrenciler ise kontrol grubunu oluşturmuştur.

\section{Çalışma Grupları}

Araştırma kapsamında yer alan çalışma gruplarını 2019-2020 eğitim-öğretim yılı birinci döneminde Kütahya ili Merkez ilçesinde bulunan bir ilkokulun iki 
farklı sınıfında öğrenim görmekte olan ikinci sınıf öğrencileri oluşturmaktadır. Bunlardan 2-D sınıfındaki 21 öğrenci deney grubu ve aynı okulda öğrenim görmekte olan 2-B sınıfındaki 20 öğrenci de kontrol grubu olarak araştırmaya dâhil edilmişlerdir. Bu gruplar, çalışma kapsamında hazırlanan öğretim tasarımının uygulanmasının öncesinde yapılan ön test ile zihinden toplama işlemi başarısı açısından istatistiksel olarak birbirine denk olacak şekilde belirlenmiş ve Bulgular bölümünün ilk kısmında bu denklik durumu detaylı biçimde açıklanmıştır. ASSURE ÖTM' ye uygun olarak tasarlanan zihinden toplama işlemi öğretimi deney grubundaki öğrencilerle beş ders saati süresince gerçekleştirilmiştir. Bu esnada, kontrol grubu kendi öğretmenleri ile matematik derslerine devam etmişlerdir. Araştırmaya katılan bu öğrencilerin araştırmaya katılma konusunda istekli ve gönüllü öğrenciler olmalarına da özen gösterilmiştir.

\section{Veri Toplama Araçları ve Verilerin Toplanması}

Nicel veriler, birinci araştırmacı tarafından geliştirilen ve toplam 10 sorudan oluşan bir başarı testinin deney ve kontrol gruplarında ön test ve son test olarak uygulanması ile elde edilmiştir. Bu testi geliştirmek için, öncelikle 2018 yılı Matematik Dersi Öğretim Programinda yer alan "Zihinden Toplama İşlemleri" konusuna ait kazanımlar incelenmiştir. Ayrıca, öğretmenlerin matematik derslerinde kullandıkları diğer kaynaklar ve konuyla ilgili öğretim materyalleri de incelenmiştir. "Zihinden Toplama İşlemleri" konusu ile ilgili kazanımlara uygun olarak toplam 10 sorudan oluşan bir başarı testi (Ek 1) geliştirilmiştir. Hazırlanan bu test, üç sınıf öğretmeninin de görüşü alınarak soruların düzeye uygunluğu ve soru biçimlerinin anlaşılırlığı bakımlarından incelenerek son haline getirilmiştir. Hazırlanan test 2019-2020 eğitim-öğretim yılı birinci döneminde ASSURE ÖTM' ye uygun olarak tasarlanan öğretimin uygulanmasının öncesinde uygulanmış ve deney-kontrol grubundaki öğrencilerin testi tamamlamaları bir ders saati sürmüştür. Aynı şekilde, öğretim tasarımının uygulanmasının ardından da yine aynı başarı testi bir ders saatinde her iki gruba uygulanmış ve ASSURE ÖTM ile teknoloji destekli olarak tasarlanan öğretimin öğrenci başarısına etkisine bakılmıştır.

Nitel veriler deney gurubundaki öğrenciler ile birinci araştırmacı tarafından yapılan görüşmelerden elde edilmiştir. Deney grubunda araştırmaya ka- 
tılan öğrenciler ile yapılan görüşmelerde, öğrencilerin zihinden işlem becerilerine bakılmıştır. Bu görüşmede toplam yedi soru sorulmuştur. Her bir öğrenciye farklı olmak üzere iki basamaklı bir sayı verilmiştir. "Bu sayıyı kaç farklı şekilde gösterebilirsin?" diye sorulmuştur. Öğrencinin bu sayıyı farklı gösterimleri ile parça bütün ilişkisini kavramsallaştırabilmesi incelenmiştir. Daha sonra her bir öğrenciye farklı bir sayı olacak şekilde iki basamaklı sayılar verilmiştir. Bu sayıları en yakın onluğa yuvarlayabilme becerilerine bakılmıştır. Daha sonra her bir öğrenciye farklı olmak üzere iki basamaklı sayılar verilmiştir. Bu sayıların önce onluklarının daha sonra birliklerinin toplanması ile sonuca ulaşılması istenilmiştir. Görüşmedeki diğer bir soruda ise öğrencilere başlangıçta tek bir sayı verilmiştir. Bu sayıdan geri/ileri onar onar sayması istenilmiştir. Zihinden toplama işleminin oluşabilmesi için gerekli becerilere öğrencilerin sahip olup olmadığı hakkında bilgiler elde edilmiştir. En son olarak öğrencilerden toplamı 50'yi geçmeyen ve 10'un katları olan sayıların toplamında zihinden işlem stratejilerini kullanabilme becerilerine bakılmıştır. Bu sorular ile öğrencilerin zihinden toplama işleminde kullandıkları stratejiler, düşünce biçimleri, ayrıca ön bilgilerinin neler olduğu bu ön bilgileri nasıl yapılandırabildikleri hakkında bilgi toplanmıştır. Ayrıca başarı testinde istenilen becerileri gerçekleştiremeyen öğrencilerin görüşme esnasında verilen ipucu, pekiştireçler ile sonucu bulması sağlanmıştır. Bu süreçte öğrenciden sorunun cevabını yazılı biçimde aktarması ve bilgisayar ortamında hazırlanan Zihinden Toplama Tablosu (ZTT) üzerinde göstermesi beklenmiştir. Ayrıca, her bir öğrenci için ayrı bir görüşme tutanağı oluşturulmuştur. Başka bir ifadeyle, görüşme notları araştırmacı tarafından yazılı olarak kayıt altına alınmıştır. Aynı zamanda, öğrencinin soruyu ne kadar sürede cevapladığı ve soruları nasıl yorumladığı bu görüşme tablosuna araştırmacı tarafından not edilmiştir. Bununla birlikte, öğrencilerin genel özelliklerinin belirlenmesi amacıyla öğrencilere birinci araştırmacı tarafından geliştirilen Kişisel Bilgi Formu çalışma öncesinde uygulanmıştır. Bu forma ilişkin detaylı bilgilere de Öğretim Materyalinin Tasarımı kısmında yer verilmiştir. Kontrol grubu ise bu süreçte kendi sınıf öğretmeni ile eğitime devam etmiştir.

\section{Verilerin Analizi}

Bu araştırma kapsamında elde edilen nicel verilerin analizi, araştırmaya katı- 
lan ikinci sınıf öğrencilerinin 2018 yılı Matematik Dersi Öğretim Programi'nda yer alan "Zihinden Toplama İşlemleri" konusuna ait kazanımlar göz önüne alınarak hazırlanmış olan ve ön-son test olarak uygulama öncesinde ve sonrasında uygulanan başarı testine vermiş oldukları cevapların analizini kapsamaktadır. Bu kapsamda, katılımcı öğrencilerin ön-son testte vermiş oldukları cevapların her biri 0 ile 5 arasında puanlanmıştır. Buna göre; "0-başarısız, 1-yetersiz, 2-geliştirilmeli, 3-orta, 4-iyi ve 5-çok iyi" biçiminde değerlendirilmiştir. Buna göre, bu ölçekten alınabilecek en yüksek puan 50 ve en düşük ise 0 olarak belirlenmiştir. Uygulanan bu başarı testi için ulaşılan veriler SPSS 24.0 programı aracılığ 1 ile analiz edilmiş ve güvenirlik katsayısı Cronbach Alfa 0.84 olarak bulunmuştur. Ulaşılan bu değer araştırmada kullanılan başarı testinin güvenilir bir test olduğunu göstermektedir. SPSS 24.0 programına aktarılan sayısal verilerin analizinde, hangi istatistiksel analizlerin kullanılacağının belirlenmesi için de verilere ilişkin çarpıklık ve basıklık katsayıları ile Shapiro-Wilk's değerleri hesaplanmıştır (Büyüköztürk, 2015 s.40). Yapılan incelemeler sonrasında, deney ve kontrol grubundaki öğrencilerden elde edilen verilerin normal dağılım özelliği göstermediği (ön test sonuçlarında Shapiro Wilk's .027 ve son test sonuçlarına göre ise .00 olarak anlamlılık düzeyleri tespit edilmiştir) ve bu nedenle de bu nicel veriler için parametrik olmayan istatistiksel tekniklerin kullanılabileceği görülmüştür. Buna göre, öğrenci gruplarından elde edilen araştırma verilerinin analizinde betimsel istatistiklerin (frekans, yüzde ve aritmetik ortalama değerleri) yanında gruplar arası ikili karşılaştırmalar için Mann Whitney U-Testi kullanılmıştır. Verilerin çözümlenmesinde ise anlamllık düzeyi .05 olarak alınmıştır.

Araştırmaya katılan deney grubundaki öğrenciler ile yapılan görüşmelerde, öğrencilerin en yakın onluğa yuvarlayabilmelerini, sayılar arasında parça-bütün bağlantısı kurabilmelerini, birlik ve onluk ayırabilmelerini, ilerigeri onar onar sayabilmelerini, toplamları 50'yi geçmeyen sayıları zihinden toplayabilmelerini, 10 ve 10 'un katlarını zihinden toplayabilmelerini ölçen sorulara verdikleri cevaplar nitel analiz yöntemlerinden betimsel analiz kullanılarak çözümlenmiştir. Betimsel analizde görüşme esnasında yer alacak boyutlardan yola çkarak bir çerçeve oluşturulur. Bu çerçeveye göre veriler işlenir. İşlenen veriler tanımlanır ve alıntılar ile desteklenir. Oluşan bulgular açıklanır, ilişkilendirilir ve yorumlanır (Yıldırım ve Şimşek, 2013, s.240). Bu çalışma kapsamında elde edilen nitel veriler yani katılımcı öğrencilerin yuka- 
rıda açıklanan bu kazanımlara yönelik becerileri için yüzde ve frekans değerleri hesaplanmış ve bu değerler bulgular kısmında açılanmıştır. Nitel verilerin yorumlanmasında, katılımcı öğrencilerin diğerlerine kıyasla daha çok güçlü oldukları stratejiler belirlenmiş, diğer stratejileri kullanabilme becerileri ve öncelik verdikleri stratejilerin nedenleri üzerinde durulmuştur. Görüşmeler sırasında belirlenen görüşme soruları ile ilgili olarak öğrenciler hiç cevap veremez ise başarısız, hatırlatma veya ipucu ile cevap verirse başarılı, müdahale olmadan cevap verirse çok başarılı olarak değerlendirilmiştir.

\section{Öğretim Materyalinin Tasarımı}

Bu bölümde, ASSURE Öğretim Tasarım Modeli'nin basamaklarına göre teknoloji destekli ve "Zihinden Toplama İşlemi" ne uygun biçimde hazırlanan materyalin/tasarımın hazırlık sürecine ilişkin detaylı bilgilere yer verilmiştir.

Öğrencilerin Analizi: ASSURE Öğretim Tasarım Modeli ile planlanan öğretim, çalışmanın yapılacağı şehir merkezinde bulunan devlet okulunun ikinci sınıfına devam eden deney grubunda (2-D sınıf) araştırmaya dâhil olan 21 öğrenci ile gerçekleştirilmiştir. Öğrencilerin çoğunluğunun sosyo-ekonomik durumunun yüksek olduğu sınıf öğretmenleri ile yapılan görüşme ile belirlenmiştir. Deney grubundaki öğrencilerden birinin Bilim Sanat Merkezi'ne devam ettiği, bir başka öğrencinin ise yabancı uyruklu olduğu tespit edilmiştir. Öğrenciler okulda bulunan çeşitli kurs faaliyetlerine ve hafta sonu etkinliklere katılmaktadırlar. Yine bu ögrenciler temel matematik becerilerine ve olumlu tutumlara sahiptirler. Ayrıca, öğrencilerin okuduğunu anlama becerisine ve olumlu sınıf kültürüne sahip oldukları da yapılan incelemelerden anlaşılmıştır. Aynı zamanda, öğrencilerin genel özellikleri öğrenciler tarafından doldurulan Kişisel Bilgi Formu ile tespit edilmiş olup öğrencilerin bu bilgileri Tablo 1'de açıklanmıştır.

Tablo 1'de görüldüğüu üzere, araştırmaya katılan öğrencilerin \%43'ü kız, \%57'si erkektir. Anaokuluna gitme süreleri açısından bakıldığında; öğrencilerin \%14.3'ünün anaokuluna gitmemiş olduğu ve \%42.9'unun ise üç yıl anaokuluna devam ettiği anlaşılmıştır. Bununla birlikte, araştırmaya dâhil olan öğrencilerin \%81'inin evinde bilgisayar bulunduğu ve öğrencilerin $\% 42.9^{\prime}$ unun bilgisayar başında vakit geçirmezken $\% 42.9^{\prime}$ unun ise günde bir saate kadar bilgisayar kullandığı anlaşılmıştır. 
Tablo 1. Araştırmaya Katılan Öğrencilerin Kişisel Özellikleri

\begin{tabular}{|c|c|c|c|}
\hline & & Sayı (f) & Yüzde (\%) \\
\hline \multirow[t]{2}{*}{ Cinsiyet } & Kiz & 9 & 43.0 \\
\hline & Erkek & 12 & 57.0 \\
\hline \multirow[t]{5}{*}{ Anaokulu Süresi } & Hiç Gitmedim & 3 & 14.3 \\
\hline & $1 Y_{1 l}$ & 3 & 14.3 \\
\hline & $2 \mathrm{Y}_{11}$ & 4 & 19.0 \\
\hline & 3 Yil & 9 & 42.9 \\
\hline & Belirsiz & 2 & 9.5 \\
\hline \multirow[t]{3}{*}{ Evinde Bilgisayar Var mı? } & Var & 17 & 81.0 \\
\hline & Yok & 3 & 14.2 \\
\hline & Belirsiz & 1 & 4.8 \\
\hline \multirow{5}{*}{$\begin{array}{l}\text { Günlük Bilgisayar Kullanma Sü- } \\
\text { resi }\end{array}$} & Hiç & 9 & 42.9 \\
\hline & $0-1$ Saat & 9 & 42.9 \\
\hline & 1-2 Saat & 1 & 4.7 \\
\hline & 2-3 Saat & 1 & 4.8 \\
\hline & Belirsiz & 1 & 4.7 \\
\hline \multirow[t]{4}{*}{ Telefon ve Tablet Kullanma Süresi } & Hiç & 1 & 4.8 \\
\hline & 0-1 Saat & 12 & 57.2 \\
\hline & 1-2 Saat & 4 & 19.0 \\
\hline & 2-3 Saat & 4 & 19.0 \\
\hline \multirow{3}{*}{$\begin{array}{l}\text { Okul Dışı Kurslara Katılma Du- } \\
\text { rumu }\end{array}$} & Katıliyor & 17 & 80.0 \\
\hline & Katılmiyor & 1 & 5.6 \\
\hline & Belirsiz & 3 & 14.4 \\
\hline \multirow[t]{3}{*}{ Sevdikleri Oyunlar } & Bilgisayar Oyunları & 0 & 0.0 \\
\hline & Bedensel Oyunlar & 21 & 100.0 \\
\hline & Zekâ Oyunları & 0 & 0.0 \\
\hline \multirow[t]{6}{*}{ En Çok Sevdiği Ders } & Matematik & 7 & 33.3 \\
\hline & Türkçe & 1 & 4.8 \\
\hline & Beden Eğitimi & 8 & 38.1 \\
\hline & Resim & 2 & 9.5 \\
\hline & Kodlama & 2 & 9.5 \\
\hline & İngilizce & 1 & 4.8 \\
\hline \multirow[t]{3}{*}{ Sosyo-Ekonomik Durum } & Yüksek & 16 & 76.1 \\
\hline & Orta & 4 & 19.1 \\
\hline & Düşük & 1 & 4.8 \\
\hline
\end{tabular}

Telefon ve tablet kullanım sürelerine bakıldığında ise \% 4.8'inin hiç kullanmaz iken \% 57.2'sinin 0-1 saat aralığında telefon ve tablet kullandığı görülmüştür. Ayrıca, öğrencilerin \%80'inin okul dışında kurslara katıldığ 1 ve tamamının bilgisayar oyunları dışındaki oyunları oynamayı daha çok sevdiği anlaşılmıştır. Bununla birlikte, araştırmaya katılan öğrencilerin \%33.3'ü matematik, \%4.8'i Türkçe, \%38.1'i Beden eğitimi, \%9.5'i resim, \%9.5'i kodlama 
ve \%4.8'i ise İngilizce dersini sevdiğini açıklamışlardır. Sosya-ekonomik verilerinin güvenirliğinin sağlanması için sınıf öğretmeni ile yapılan görüşme neticesinde öğrencilerin sosyo-ekonomik durumlarını \%76.1'i yüksek, $\% 19.1$ 'i orta ve \%4,8'i düşük olduğu tespit edilmiştir.

Bu araştırmaya katılan ve ASSURE ÖTM' ye göre hazırlanan dersin uygulandığı öğrencilerde gerçekleşmesi beklenen ön gereksinimler aşağıda verilmiştir:

- Öğrencilerin temel matematik becerilerine sahip olmaları beklenmektedir.

- En yakın onluğa yuvarlayabilmeleri beklenmektedir.

- İleri-geri sayma becerilerine sahip olmaları beklenmektedir.

- Onar onar ileri ve geri sayma becerilerine sahip olmaları beklenmektedir.

- Parça-bütün ilişkisine sahip olmaları beklenmektedir.

Öğrencilerden beklenilen bu yeterliliklere ilişkin durumları uygulamalar öncesinde yapılan ön test ile tespit edilmiştir. Ulaşılan sonuçlara da, araştırmanın Bulgular kısmında yer verilmiştir.

Öğrenme Hedeflerinin Belirlenmesi: İlkokul ikinci sınıf öğrencilerinin belirli stratejileri kullanarak, araştırma kapsamında uygulamalar için geliştirilen program aracılığ ile zihinden toplama işlemlerini yapabilmeleri sağlanmıştır. Zihinden toplama işleminde ulaşılması gereken öğretim hedefleri de 2018 yılı Matematik Dersi Öğretim Programı'ndaki kazanımlara göre aşağıdaki şekilde belirlenmiştir:

- Toplamları en fazla 100 olan 10 ve 10'un katı olan doğal sayılarla zihinden toplama işlemleri yapılır.

- Ardından toplamları 50'yi geçmeyen iki doğal sayıyı zihinden toplama çalışmalarına yer verilir.

- Parça-bütün ilişkisini kavrayabilir.

- İleri-geri sayabilir.

- Illeriye ve geriye onar ritmik sayma yapabilir.

- Sayıyı en yakın onluğa yuvarlayabilir.

Yukarıdaki hedeflere ulaşabilmek için araştırma kapsamında ASSURE Öğretim Tasarım Modeli'ne uygun olarak teknoloji destekli öğretimden de yararlanılarak hazırlanan öğretim/ders planı, Millî Eğitim Bakanlığı 2005 y1lından itibaren hazırlanan programlarda yer alan ve eğitim sisteminde uygulanmak üzere benimsenen Yapılandırmacı Yaklaşım'a uygun olarak planlanmıştır. Bu yaklaşımla, öğrencilerden bilgilerini kendi gelişimsel özelliklerine 
uygun olarak kendi çabaları ile yapılandırmaları beklenmektedir. Bu süreçte, öğrenciler önceki bilgilerini geliştirirken aktif rol oynamaktadırlar ve öğretmen etkileşimli bir rol seçerek öğrenciye yol göstermekte, öğrenciyi teşvik etmektedirler (Fidan ve Duman, 2014). Ders planlaması esnasinda dersin genel kurgusunun da Yapılandırmacı Yaklaşım'a uygun strateji, yöntem ve tekniklerin seçilmesi gerekmektedir. Bu nedenle, bilginin yapılandırılmasını ve kalıclığını sağlayan modellerden de 7E Modeli araştırma için belirlenmiştir. Bu model ile planlanan bir uygulama/ders sürecinde, öğrencilerle modelin aşamaları sistematik olarak uygulanmaktadır. Bununla birlikte, istenilen öğrenme hedeflerine ulaşmada, deney grubundaki tüm öğrenciler için öğrenme sağlayabilmek için klasik yöntemlerden ziyade teknolojinin kullanılması Zihinden Toplama İşlemi'nin öğretimi için uygun ve zorunlu kabul edilmiştir (Camnalbur, 2008). Bu nedenle, öğretim planlaması yapılırken ASSURE Öğretim Tasarım Modeli'nin doğasına en uygun teknik olan Teknoloji Destekli Öğretim yöntemi seçilmiştir (Karakış, 2014).

Medya ve Materyallerin Seçimi: Bu basamakta, öğrenci grubu için en uygun olduğu düşünülen, öğrenme hedeflerine daha iyi ulaştırabilecek medya ve materyallerin seçimi yapılmıştır. Bu kapsamda, öğrencilerin önceki bilgileri ile var olan yeni durumu yapılandırabilmeleri, eksik öğrenmelerini kendileri keşfedebilmeleri, güçlü yönlerinin farkına varabilmeleri için teknoloji destekli öğretimin doğasına da uygun olarak üç farklı bilgisayar programı hazırlanmıştır. Bu programlardan birincisi, birinci araştırmacı tarafından Animarker programı kullanılarak yapılan bir video tasarımıdır. İkincisi ise, yine birinci araştırmacı tarafından Web 2.0 araçlarından LearningApps kullanılarak tasarlanan Eşleştirme Kartları ve Yüzlük Sayı Doğrusu'dur. Bunlara ek olarak, bir bilgisayar programcısından da destek alınarak birinci araştırmacı tarafından tamamen orijinal olan ve çalışmanın ana temelini oluşturan Zihinden Toplama Tablosu (ZTT) geliştirilmiştir.

Animarker kullanılarak tasarlanan videoda, zihinden toplama işleminin önemini anlatan bir karakter üzerinden öğrencilerin ilgilerinin çekilmesi amaçlanmıştır. LearningApps kullanılarak yapılan Eşleştirme Kartları ve Sayı Doğrusu ile öğrencilerin ön bilgilerini güçlendirmek amaçlanmış ve parça-bütün, üzerine 10 sayma gibi etkinlikler planlanmıştır. Bu araştırma için geliştirilen ZTT programı, öğrencilerin oyun oynayarak öğrendiklerini yapılandırması için tasarlanmıştır. Uygulamaya girildiğinde, bilgisayar ekranında yüzlük tablo, onluk toplam ve sayı toplamı olmak üzere iki buton ve 
sayıların yenilenmesini sağlayacak bir yenileme butonu ile birlikte zamanlayıcı bulunmaktadır. Uygulama çalıştırıldığında, öğrencilerin karşısına her defasında farklı sayılar gelmektedir. İlk sayı kadar bölüm yüzlük tabloda boyanmaktadır. Öğrenci istediği stratejiyi kullanarak sonuca ulaşmaya çalışmakta ve zamanlayıcı sayesinde de kendi öğrenme hızının farkına varabilmektedir. Bu programda yer alan yüzlük tablo anasınıfından ikinci sınıfa kadar çocukların basamak değerlerinin kavramasında, onluk tabanı ve sayıları tanımasında etkilidir. Buradan hareketle, uygulamalarda öğrenciler yüzlük tablo aracılığı ile çok sayıda örüntü fark edebilirler. Böylece, çocukların bu tabloları kullanarak toplama işleminin birçok yolu olduğunu fark edebilirler (Van de Walle, Karp ve Bay-Williams 2016, s.200).

Medya ve Materyallerin Kullanımı: Bu aşamada, öğrencilerin medya ve materyalleri kullanmadan önce denemesi sağlanmakta ve çıkabilecek aksaklıklar tespit edilerek giderilmektedir.

Öğrenenlerin Katılımının Sağlanması: Bu aşamada, teknoloji destekli öğretim ve 7E öğretim modelinin aşamaları kullanılarak öğrencilerin aktif katılımı sağlanır. Bu aşamalar; merak uyandırma, keşif, açıklama, genişletme, ilişkilendirme, paylaşmalfikir alışverişi ve değerlendirmedir (Bybee, 2003, Akt. Öztürk, 2017, s.118). Aşağıda bu araştırma kapsamında ASSURE Öğretim Tasarım Modeli üzerinden hazırlanan öğretimin 7E Öğretim Modeli ile uygulanması esnasında yapılanlar detaylı biçimde aşağıda açıklanmıştır:

1-Merak Uyandırma: Öğretmen uygulamayı başlatmak için deney grubundaki öğrencilerin bulunduğu sınıfa girdiğinde, öğrencilere hazırlamış olduğu videoyu açar. Videoda kullanılan karakter, öğrencilere zihinden toplama işleminin gerekliliğini anlatmak için günlük hayattan ve yaşantılarından örnekler verir. Günlük yaşantılarında yaptıkları alışverişleri ve oyunlarındaki hesapları nasıl elde ettiklerini öğrencilere sorar. Öğretmen bu esnada öğrencilerin cevapların değerlendirerek ön bilgilerini yoklar. Bu hesaplamaları yaparken, öğrencilerin yanında getirmiş olduğu hesap makinesi, bilgisayar ve kalem gibi aletleri her zaman yanlarında taşıyamayacakları ve bunlara ihtiyaç olmadan da doğru stratejileri kullanarak toplama yapmanın çok kolay olduğunu açıklar. Böylelikle, Van de Walle (1994) hesaplamanın dört aşaması olan yazılı hesap, zihinden hesap, tahmini hesap ve hesap makinesi veya bilgisayarla hesaba dikkat çekmiş olur (Akt. Yazgan, Bintaş ve Altun, 2002). 
Araştırmacı, öğrencilerin ön bilgilerini yoklamak için beyaz tahta/eşleştirme kartları ile alt kazanımları tekrar etmiştir. Birinci dersin bitmesiyle öğrencilerin merakı derse çekilmiş ve ön bilgileri de tekrar edilmiştir.

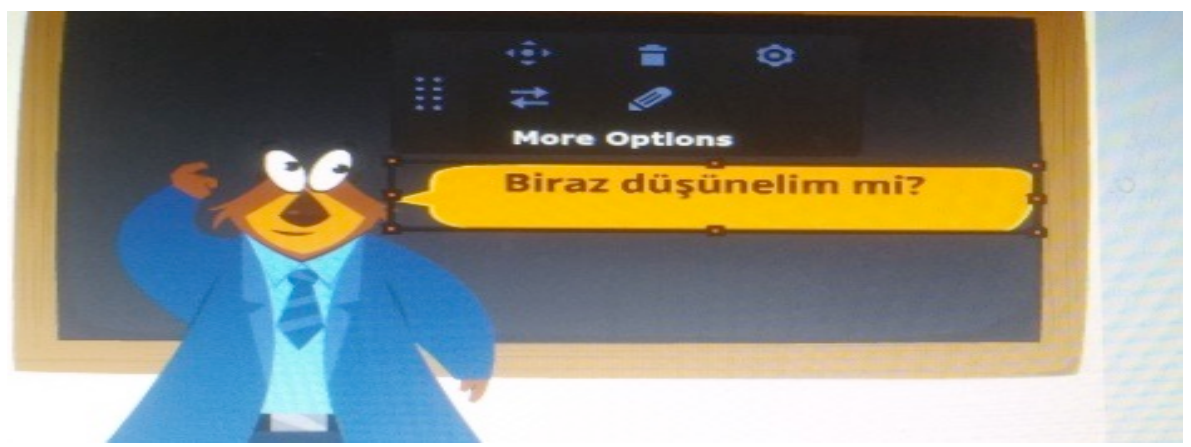

\section{Şekil 1. Video Gösterimi}

2-Keşfetme-Açıklama: Bu uygulamayı birinci araştırmacı yapmıştır ve öğretmen rolünde olan bu araştırmacı hazırlanan tasarımın uygulandığı ikinci derse girerken, ilk olarak önceki dersin tekrarını yapmak için yeniden Şekil 1 'deki görüntüsüne yer verilen videoyu açar. Böylelikle, öğrencilerin ilgi, istek ve meraklarını üst seviyede tutmaya çalışır. Bu aşamada, günlük hayatta zihinden toplama işlemine ne kadar sıklıkla başvurulduğu konusunda öğrenciler ile sohbet edilir. Onlara kendi hayatlarının içinden öğrenme firsatları sunulur. Her bir öğrenciden kendi öğrenme yaşantısını oluşturması için kullandığı stratejileri defterine kaydetmesi istenir. Öğrenciler kendi öğrenme stratejilerini bulduktan sonra öğretmen, öğrencilerinin bulmuş olduğu benzer ve farklı stratejileri (1-Onluk ve birliklerine ayırarak 2-Üzerine Sayma 3En yakın onluğa tamamlama) üç gruba ayırmak için sınıf tahtasını üçe böler. Tahta da yapmış olduğu her bir stratejiyi de hazırlanan bilgisayar programı olan şekil 2'deki ZTT' de öğrencilere gösterir.

Öğrencilerin zihinden toplama işlemi yaparken kullandıkları stratejileri tahtada uygun bölüme yazar. Bu şekilde birkaç tane sayıy daha modeller. Ardından, öğrencilerin tahtaya yazılan stratejiler üzerinde düşünmeleri sağlanır. Öğretmen öğrencilerden kullanmış oldukları farklı stratejileri defterlerine not almalarını ister. Bu aşamada, öğrencilerin sayıları parça-bütün, en yakın onluğa yuvarlama ve ileri-geri sayma gibi becerileri yapabilmeleri için 
bireysel çalışmalara dönmeleri ve farklı stratejileri deneyerek sonuca ulaşabilmeleri sağlanır. Bu esnada, öğrencilerin zihinlerindeki sorulara cevap aranır ve öğretmenin serbest tartışma ortamı oluşturarak öğrencilerin zihinden toplama stratejileri ile ilgili bilgilerini sunmalarına firsat vermesi gerekir. Ayrıca, hazırlanan ZTT bilgisayar programı ile anlatım, soru cevap, gösteri gibi teknikler kullanılarak öğrencilere stratejileri hakkında bilgi aktarır. Bu aşamada, öğrencinin zihninde var olan hatalı ve eksik algılamaları doğru biçimde değiştirilir. Böylelikle, öğrencinin yeni bilgileri yapılandırması sağlanır. Bu esnada, öğrenci bol miktarda alıştırma yapmalı, bir bilim insanı gibi hareket ederek gözlem yapmalı, verileri kaydetmeli, değişkenleri belirlemeli, sayılar arasındaki ilişkileri görebilmeli, sayılar ile konuşabilmelidir. İki ders saati süren uygulamanın bu kısmına ilişkin olarak aşağıdaki şekillerde ZTT'nin kullanım aşamaları temsili olarak gösterilmiştir. "29+12" işlemi yapılırken, yukarıdaki açıklamalar doğrultusunda öğrenciler tercihlerine göre tabloyu kullanabilir. Aşağıda ise, bir öğrencinin ZTT'yi kullanımı gösterilmektedir.

29+12= Toplama işlemi (Şekil 2)

29+1 = En yakın onluğa tamamlama (Şekil 3)

30+10= Üzerine 10 ekleme, parça-bütün ilişkisi (Şekil 4)

40+1 = Üzerine ekleme - sayma (Şekil 5)

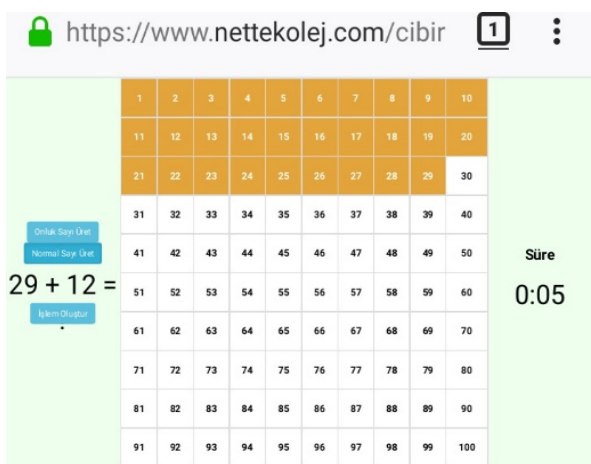

Şekil 2. Toplama İslemi

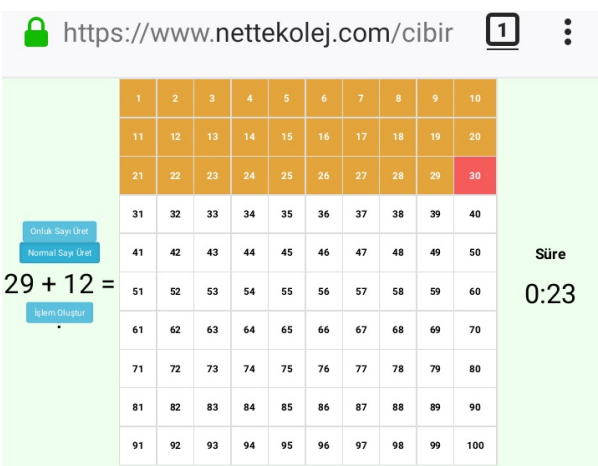

Şekil 3. En yakın onluğa tamamlama 


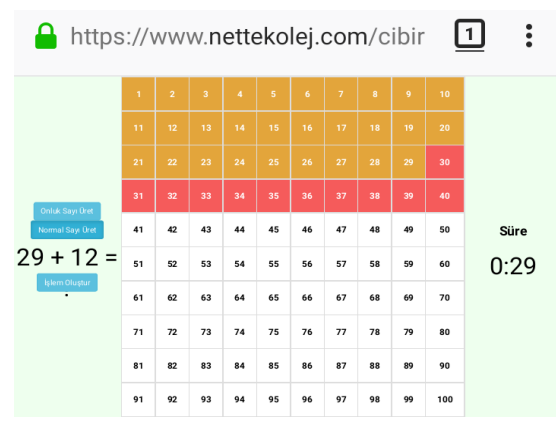

Şekil 4. Üzerine on ekleme

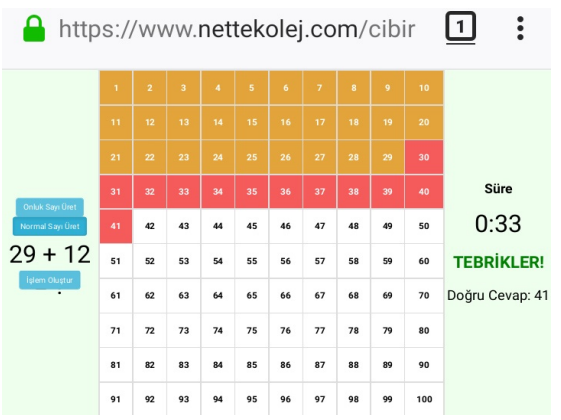

Şekil 5. Üzerine Sayma

3-Genişletme-İlişkilendirme-Paylaşma: Uygulama kapsamındaki dördüncü derse girilirken öğrencilere hazırlanmış olan video gösteri yeniden izletilir. Ardından, önceki dersler ile ilgili genel bir tekrar yapılır. Sonrasında, öğren-

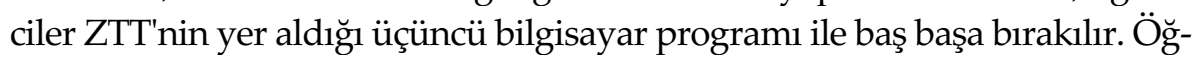
renciye gerçek yaşam ile ilgili yeni bazı deneyimler sunulur ve öğrencilerden öğrenmiş olduğu yeni bilgiyi artık genişletebilmesi ve kullanabilmesi beklenmektedir. Bu aşamada, toplama işlemi yapılırken zihin, öğrenciler fark etmese de bazı yöntemleri kullanarak sonuca ulaşmaktadır. Zihinden toplama işlemi bu yolların görülmesini sağlar ve bu yollar her öğrencide farklı biçimde gelişebilir. Bundan dolayı, zihinden toplama işlemlerinin tek bir yöntemi yoktur ve öğrenci çözümde kendini en güçlü hissettiği yöntemleri kullanmaktadır.

Öğrenciler öğrenmiş oldukları yeni bilgileri arkadaşları ile paylaşabilmesi gerekmektedir. Böylelikle farklı fikirleri de görmüş olarak kendi fikirlerine daha geniş bir pencereden bakmış olur. Ayrıca, öğrencinin belli bir süre dijital ekranda öğrencilerin öğrenme serüvenleri baş başa kalması sağlanmalı, ardından da bulmuş oldukları sonuçları arkadaşları ile tartışabilmeli ve böylelikle birbirlerinin uygulamış oldukları farklı stratejileri fark edebilmelidirler

ZTT tasarlanırken öğrencilerin sayılar arasındaki niceliksel ilişkileri ve sayı örüntülerini fark edebilmesi beklenmektedir. Bu sayede, öğretmen, öğrencilerin kullanmış oldukları stratejilerde onların akıl yürütmelerine, karar verme süreçlerine, örüntüler ve nicelikler arasındaki ilişkiye yönelik esnek düşünebilmelerine firsatlar tanınmış olur (Lubinski ve Otto, 1997, s.85). 
Öğrencilere ev ödevi olarak günlük olaylardan hangilerini zihinden işlemler ile çözebilecekleri konusunda bilgilendirmeler yapılır. Onlardan öğrenmiş oldukları bu yeni durumlar ile ilgili günlük yaşantılarından örnekler vermeleri istenir. Ayrıca gün içerisinde karşılaştıkları problemleri not etmelerini ve zihinden işlem stratejileri ile çözüm yollarını deftere yazmaları istenilir.

4-Değerlendirme: Uygulamanın beşinci dersinde yapılan değerlendirmede başarı testi kullanılarak öğrencilerin öğrenme durumları gözden geçirilir. Ayrıca, ders içinde öğrenciler gözlemlenerek durumları hakkında bilgi alınır.

Değerlendirme ve Düzeltme: ASSURE Öğretim Tasarım Modeli'nin değerlendirme aşamasında, modelin etkili olup olmadığını tespit edebilmek amacıyla ön test ve son test yapılmıştır. Bu kapsamda, değerlendirme aşamasında deney ve kontrol grubu karşılaştırılmış ve elde edilen sonuçlar da Bulgular kısmında sunulmuştur. Kullanılan materyalin nasıl bir etki yaptığını anlayabilmek için geliştirilen başarı testinin geçerlik ve güvenirliklerine bakılmış, testin geçerli ve güvenilir olduğu çalışmanın Yöntem bölümünde Veri Toplama Araçları kısmında detaylı biçimde açıklanmıştır. Bu başarı testinde yer alan soruların ilişkili oldukları kazanım ve alt kazanımların sorulara dağılımına da aşağıda yer alan Tablo 2' de yer verilmiştir.

Tablo 2. Akademik Başarı Testi Soruların Faktörlere göre Dağılımı

\begin{tabular}{ll}
\hline & Soru Dağılımları \\
\hline Sayıları Onluk ve Birliklerine Ayırma & 1,7 \\
Sayılar Arasında Parça-Bütün Bağlantısı Kurabilme & 2,9 \\
Sayıları En yakın Onluğa Tamamlayabilme & $3,6,8$ \\
Sayıların Üzerine Sayabilme & $4,5,10$ \\
Toplamları en fazla 100 olan 10 ve 10'un Katı Doğal Sayılarla Zih.Top. İş.Y. & 5,6 \\
Toplamları 50'yi Geçmeyen İki Doğal Sayıyı Zihinden Toplayabilme & $1,2,3,4,7,8,9,10$ \\
\hline
\end{tabular}

$\mathrm{Bu}$ araştırma kapsamında geliştirilen öğretim tasarım modeli incelenmiş, hazırlanan ve uygulamanın başlangıç kısmında kullanılan videodan sonra, öğretmen öğrencilerin ön bilgileri kontrol etmek için Web 2.0 araçlarını kullanmasının daha etkili olacağına karar verilmiştir. Uygulamaya Web 2.0 araçları ile Eşleştirmeli Kartlar eklenerek öğretimin etkililiği arttırılmıştır. Ayrıca örnek uygulamaların ardından bu araştırma için geliştirilen ZTT'de, bazı düzeltmelerin gerekliliği ön görülmüştür. Bu kapsamda, tablodaki sayıları sistemin değil öğretmenin tayin etmesinin daha verimli olacağı belirlenmiş ve 
tablo buna uygun olacak şekilde düzenlenmiştir. Ayrıca, yapılan incelemelerde programdaki tabloda sayıları bir kereye mahsus geriye götürülmesi, uygulayıcının hayal gücünü zayıflatabilmektedir. Yine de, ZTT ve video programı deney grubunda araştırmaya katılan tüm öğrencilerin ilgisini çekmiştir. Çünkü bu materyal öğrencilere toplama işlemini eğlenceli olarak uygulama fırsatı vermekte ve öğrencilerin sayılar arasındaki ilişkileri fark edebilmelerine de yardımcı olmaktadır.

\section{Bulgular ve Yorum}

Bu bölümde, ASSURE Öğretim Tasarım Modeli'ni kullanarak planlanan bir matematik öğretim tasarımının öğrencilerin Zihinden Toplama işlemleri üzerindeki etkilerini incelemek amacıyla gerçekleştirilen analiz sonuçlarına ve bu sonuçların yorumlanmasına yer verilmiştir.

\section{Zihinden Toplama İşlemine Yönelik Nicel Analiz Bulguları}

Bu araştırmada, ilkokul ikinci sınıf öğrencilerine tasarım uygulamasının öncesinde ve sonrasında birinci araştırmacı tarafından hazırlanan başarı testi uygulanmıştır. Ön test ve son test olarak yapılan başarı testi puanlarına ilişkin istatistiksel analiz sonuçlarına da aşağıdaki tablolarda yer verilmiştir.

Nicel verilerin analizi kapsamında araştırmaya dahil edilen 2-B (kontrol) ve 2-D sınıfı (deney) öğrencilerinin zihinden toplama işlemini yapabilme becerileri ve zihinde toplama işleminin belirlenen faktörleri açısından birbirlerine istatistiksel olarak anlamlı düzeyde denk oldukları aşağıda yer alan Tablo 3 ve Tablo 4'te gösterilmiştir.

Tablo 3. Deney ve Kontrol Grubundaki Öğrencilerin Zihinden Toplama İşlemi Ön Test Puanlarna ilişkin İstatistiksel Analiz Sonuçlar

\begin{tabular}{llllll}
\hline Ön Test & $\mathrm{n}$ & Sira Ortalamasi & Sira Toplami & $\mathrm{U}$ & $\mathrm{p}$ \\
\hline Deney Grubu & 21 & 20.98 & 440.50 & 209.50 & 0.99 \\
Kontrol Grubu & 20 & 21.03 & 420.50 & & \\
\hline
\end{tabular}

Tablo 3 incelendiğinde, deney ve kontrol grubu öğrencilerinin başarı testine yönelik ön test puanları arasında istatistiksel olarak anlamlı düzeyde bir farklılık görülmemektedir ( $U=209.50$, p >.05). Bu durumda deney ve kontrol 
grubundaki öğrencilerin zihinsel toplama işlemlerini yapabilmeleri açısından istatistiksel olarak denk olduklarına işaret etmektedir. Bununla birlikte, sıra ortalamaları dikkate alındığında da kontrol grubu öğrencilerinin puanlarının deney gurubu öğrencilerinin puanlarına kıyasla daha yüksek olduğu anlaşılmıştır.

Tablo 4. Deney ve Kontrol Grubundaki Öğrencilerin Zihinden Toplama İşlemi Faktörleri için Hesaplanan Ön Test Puanlarına ilişkin İstatistiksel Analiz Sonuçları

\begin{tabular}{|c|c|c|c|c|c|c|}
\hline & Ön Test & $\mathrm{n}$ & $\begin{array}{l}\text { Sira } \\
\text { Ortalaması }\end{array}$ & $\begin{array}{l}\text { Sira } \\
\text { Toplamı }\end{array}$ & $\mathrm{U}$ & $\mathrm{p}$ \\
\hline \multirow{4}{*}{$\begin{array}{l}\text { Onluk ve Birlik } \\
\text { Ayırma }\end{array}$} & Deney & 21 & 19.26 & 404.50 & 173.50 & 0.32 \\
\hline & Grubu & & & & & \\
\hline & Kontrol & 20 & 22.83 & 456.50 & & \\
\hline & Grubu & & & & & \\
\hline \multirow[t]{4}{*}{ Parça-Bütün İlişkisi } & Deney & 21 & 19.14 & 402.00 & 171.00 & 0.30 \\
\hline & Grubu & & & & & \\
\hline & Kontrol & 20 & 22.95 & 459.00 & & \\
\hline & Grubu & & & & & \\
\hline \multirow{3}{*}{$\begin{array}{l}\text { En Yakın Onluğa } \\
\text { Yuvarlama }\end{array}$} & Deney & 21 & 22.38 & 470.00 & 181.00 & 0.44 \\
\hline & Grubu & & & & & \\
\hline & $\begin{array}{l}\text { Kontrol } \\
\text { Grubu }\end{array}$ & 20 & 19.55 & 391.00 & & \\
\hline \multirow{3}{*}{$\begin{array}{l}\text { Üzerine Sayma } \\
\text { Yöntemi }\end{array}$} & Deney & 21 & 22.10 & 464.00 & 166.00 & 0.36 \\
\hline & Grubu & & & & & \\
\hline & Kontrol & 20 & 18.74 & 356.00 & & \\
\hline
\end{tabular}

Tablo 4 incelendiğinde, deney ve kontrol grubundaki öğrencilerin başarı testinde yer alan Zihinden Toplama İşlemi Faktörleri (onluk ve birlikleri ayırma, parça-bütün ilişkisi, en yakın onluğa yuvarlama, üzerine sayma) için hazırlanan tasarımın uygulanması öncesinde yapılan başarı testinden aldıkları puanlar arasında da yine istatistiksel olarak anlamlı düzeyde farklılıklara ulaşılamamıştır ( $\mathrm{U}_{\mathrm{o}}=173.50, \mathrm{U}_{\mathrm{P}}=171.00, \mathrm{U}_{\mathrm{E}}=181.00$ ve $\left.\mathrm{U}_{\mathrm{u}}=166.00 ; \mathrm{p}>.05\right)$. Sıra ortalamaları dikkate alındığında, kontrol grubu öğrencilerinin "onluk ve birlik ayırma" ve "parça-bütün ilişkisi" faktörleri için uygulama öncesinde başarı testinden aldıkları puanların, deney gurubu öğrencilerine kıyasla daha yüksek olduğu anlaşılmaktadır. Aksine yine sıra ortalamaları dikkate alındığında, deney grubu öğrencilerinin "en yakın onluğa yuvarlama" ve "üzerine sayma" faktörleri için başarı testinden aldıkları puanların, kontrol gurubu öğrencilerinin puanlarına kıyasla daha yüksek olduğu anlaşılmaktadır. 
Bu araştırma kapsamındaki nicel verilerin analizinde, "İlkokul ikinci sınıfta ASSURE Öğretim Tasarım Modeli aracılığı ile geliştirilen öğretim tasarımı, öğrencilerin "Zihinden Toplama İşlemi"ndeki başarıları açısından istatistiksel olarak anlamlı düzeyde farklılık oluşturmakta mıdır?" biçimindeki birinci araştırma problemine cevap aranmıştır. Bu kapsamda, deney ve kontrol grubundaki öğrencilere son test olarak uygulanan başarı testinden elde edilen nicel verilerin istatistiksel analizi sonucunda elde edilen bulgular Tablo 5'te açıklanmıştır.

Tablo 5. Deney ve Kontrol Grubundaki Öğrencilerin Zihinden Toplama İşlemi Son Test Puanlarna ilişkin İstatistiksel Analiz Sonuçlan

\begin{tabular}{llllll}
\hline Son Test & $\mathbf{n}$ & $\begin{array}{l}\text { Sira } \\
\text { Ortalaması }\end{array}$ & Sira Toplamı & U & p \\
\hline Deney Grubu & 21 & 26.33 & 553.00 & 98.00 & 0.003 \\
Kontrol Grubu & 20 & 15.40 & 308.00 & & \\
\hline
\end{tabular}

Tablo 5 incelendiğinde, deney ve kontrol grubu öğrencilerinin başarı testi son test puanları arasında istatistiksel olarak anlamlı düzeyde bir farklılığa ulaşılmıştır ( $U=98.00, p<.05)$. Sıra ortalamaları dikkate alındığında, ön test için yapılan istatistiksel analizlerin aksine deney grubu öğrencilerinin puanlarının kontrol grubu öğrencilerinin puanlarına kıyasla oldukça yüksek olduğu anlaşılmıştır. Bu bulguya göre deney grubundaki öğrencilerin zihinden toplama işleminde kontrol grubuna kıyasla daha başarılı olduğu söylenebilir.

$\mathrm{Bu}$ araştırma kapsamında nicel analiz verilerinin analizinde, "Illkokul ikinci sınıfta ASSURE Öğretim Tasarım Modeli aracılığı ile geliştirilen öğretim tasarımı, öğrencilerin "Zihinden Toplama İşlemi" faktörleri (Onluk ve birliklere ayırma, parça-bütün ilişkisi kurma, sayıları en yakın onluğa yuvarlayabilme, üzerine sayma yapma) açısından istatistiksel olarak anlamlı düzeyde farklılık oluşturmakta mıdır?" biçimindeki ikinci araştırma problemine cevap aranmıştır. Bu kapsamda, deney ve kontrol grubundaki öğrencilere son test olarak uygulanan başarı testinden elde edilen nicel veriler Zihinden Toplama İşlemi Faktörleri açısından değerlendirilmiş ve yapılan istatistiksel analizler sonucunda elde edilen bulgulara da Tablo 6 'da yer verilmiştir.

Tablo 6 incelendiğinde, deney ve kontrol grubundaki öğrencilerin başarı testinde yer alan Zihinde Toplama İşlemi Faktörleri'nden (onluk ve birlikleri ayırma, parça-bütün ilişkisi, en yakın onluğa yuvarlama ve üzerine sayma) 
için son test olarak uygulanan başarı testinden aldıkları puanları arasında istatistiksel olarak anlamlı düzeyde farklılıklara ulaşılamamıştır ( $\mathrm{Uo}_{\mathrm{o}}=146.00$, $U_{p}=143.50, U_{E}=191.00$ ve $\left.U_{u}=161.00 ; p>.05\right)$.

Tablo 6. Deney ve Kontrol Grubundaki Öğrencilerin Zihinden Toplama İşlemi Faktörleri için Hesaplanan Son Test Puanlarna ilişkin İstatistiksel Analiz Sonuçlarn

\begin{tabular}{|c|c|c|c|c|c|c|}
\hline & Son Test & $\mathbf{n}$ & $\begin{array}{l}\text { Sira } \\
\text { Ortalaması }\end{array}$ & $\begin{array}{l}\text { Sira } \\
\text { Toplamı }\end{array}$ & $\mathbf{U}$ & $\mathrm{p}$ \\
\hline Onluk ve Birlik & Deney Grubu & 21 & 24.05 & 505.00 & 146.00 & 0.052 \\
\hline Ayırma & Kontrol Grubu & 20 & 17.80 & 356.00 & & \\
\hline \multirow[t]{2}{*}{ Parça Bütün İlişkisi } & Deney Grubu & 21 & 24.17 & 507.50 & 143.50 & 0.064 \\
\hline & Kontrol Grubu & 20 & 17.68 & 353.50 & & \\
\hline En Yakın Onluğa & Deney Grubu & 21 & 21.90 & 460.00 & 191.00 & 0.615 \\
\hline Yuvarlama & Kontrol Grubu & 20 & 20.05 & 401.00 & & \\
\hline Üzerine Sayma & Deney Grubu & 21 & 23.33 & 490.00 & 161.00 & 0.196 \\
\hline Yöntemi & Kontrol Grubu & 20 & 18.55 & 371.00 & & \\
\hline
\end{tabular}

Sıra ortalamaları dikkate alındığında, ön test puanlarından elde edilen sonuçların aksine "onluk ve birlik ayırma" ve "parça-bütün ilişkisi" faktörleri için deney grubu öğrencilerinin uygulama sonrası başarı testinden aldıkları puanların kontrol grubu öğrencilerine kıyasla daha yüksek olduğunu göstermektedir. Ayrıca yine sıra ortalamalarına bakıldığında, deney grubu öğrencilerinin "en yakın onluğa yuvarlama" ve "üzerine sayma" faktörleri için uygulama öncesi ve sonrası için hesaplanan başarı testi puanlarının kontrol grubundaki öğrencilerin puanlarından daha yüksek olduğu görülmüştür. Bu durum, deney grubundaki öğrencilerin bu faktörlerdeki başarılarını devam ettirdiklerine işaret etmektedir. Yapılan öğretim tasarımının uygulanması sonrasında deney grubundaki öğrencilerin "onluk ve birlik ayırma" ve "parça-bütün ilişkisi" faktörleri açısından da başarının arttığını göstermiştir.

\section{Zihinden Toplama İşlemine Yönelik Nitel Analiz Bulguları}

Bu araştırma kapsamındaki nitel analiz verilerinin analizinde, üçüncü araştırma problemi olan "İlkokul ikinci sınıfta ASSURE Öğretim Tasarım Modeli aracilı̆̆ ile geliştirilen öğretim tasarımı, öğrencilerin "Zihinden Toplama İşlemi"ne ait kazanımları gerçekleştirebilmeleri açısından farklılık oluşturmakta mıdır?" biçimindeki üçüncü araştırma problemine cevap aranmıştır. 
Bu kapsamda, deney grubundaki 21 öğrenciye zihinden toplama işlemi başarı durumlarının tespit edilmesine yönelik toplam yedi soru yöneltilmiştir. Bu görüşmelerin sonrasında, öğrencilerin zihinden toplama işlemine ait kazanımları gerçekleştirebilme durumları betimsel analiz aracılığı ile incelenmiştir. Ulaşılan analiz sonuçları da aşağıda yer alan Tablo 7'de yüzde ve frekans değerleri ile birlikte verilmiştir.

Tablo 7. Katılımcı Öğrencilerin İfadelerinin Araştırma Problemlerine Dağılımı

\begin{tabular}{|c|c|c|c|c|c|c|}
\hline \multicolumn{7}{|c|}{ Beklenilen Başarı Düzeyleri } \\
\hline & \multicolumn{2}{|c|}{ Başarısız } & \multicolumn{2}{|c|}{ Başarılı } & \multicolumn{2}{|c|}{ Çok Başarılı } \\
\hline Görüşmede Öğrencilerden & $\mathrm{f}$ & $\%$ & $\mathrm{f}$ & $\%$ & $\mathrm{f}$ & $\%$ \\
\hline \multicolumn{7}{|l|}{ Beklenen Kazanımlar } \\
\hline En Yakın Onluğa & 1 & 4.8 & 3 & 14.3 & 1 & 80.9 \\
\hline Yuvarlayabilir & & & & & 7 & \\
\hline Sayılar Arasında Parça-Bütün & 2 & 9.5 & 4 & 19.0 & 1 & 71.5 \\
\hline Bağlantısı Kurabilme & & & & & 5 & \\
\hline \multirow[t]{2}{*}{ Onluk ve birliklerine Ayırabilir } & 0 & 0.0 & 3 & 14.2 & 1 & 85.8 \\
\hline & & & & & 8 & \\
\hline \multirow[t]{2}{*}{ İleriye Onar Onar Sayabilir } & 0 & 0.0 & 5 & 23.8 & 1 & 76.2 \\
\hline & & & & & 6 & \\
\hline \multirow[t]{2}{*}{ Geriye Onar Onar Sayabilir } & 0 & 0.0 & 5 & 23.8 & 1 & 76.2 \\
\hline & & & & & 6 & \\
\hline Toplamları 50'yi Geçmeyen & 1 & 4.8 & 3 & 14.2 & 1 & 80.9 \\
\hline Sayıları Zihinden Toplayabilir & & & & & 7 & \\
\hline 10 ve 10 'un Katlarını Zihinden & 0 & 0.0 & 3 & 14.3 & 1 & 85.7 \\
\hline Toplayabilir & & & & & 8 & \\
\hline
\end{tabular}

Tablo 7'de verilen yüzde ve frekans değerlerinde hareketle, deney grubundaki öğrencilerin kendilerinden beklenen kazanımların her biri için başarılı olma durumlarına ilişkin açıklamalara aşağıda yer verilmiştir.

En Yakın Onluğa Yuvarlayabilme: Öğrencilerin zihinden toplama işlemlerine ait kazanımları gerçekleştirebilmeleri için öncelikle bazı alt kazanımları yapabilmeleri beklenmektedir. Bunlardan belki de en önemlisi en yakın onluğa yuvarlayabilmedir. Yapılan incelemelerde, öğrencilerin \%80.9'unun herhangi bir yardım ya da destek olmaksızın oldukça başarılı, \%14.3'ünün ise küçük yol gösterme ve yardımlarla başarılı olduğu saptanmıştır. Başarısız olan bir öğrencinin ise 25 ve 35 gibi sayıları en yakın onluğa yuvarlarken bir alt onluğa yuvarladığı tespit edilmiştir.

Sayılar Arasında Parça-Bütün Bağlantısı Kurabilme: Öğrencilerde sayı kavramının, hissinin oluşmasının göstergelerinden birisi en temel matematik 
becerisi olan sayılar arasında parça-bütün ilişkisi kurabilmektir. Aynı zamanda, bu bağlantıyı kurabilmeleri zihinden işlemlerin en temel bileşenini oluşturmaktadır. Yapılan çalışma sonunda, gerçekleştirilen görüşmelerde öğrencilerin \% 71.5' inin herhangi bir yardım ya da destek olmaksızın oldukça başarıll, \%19.0'ının ise küçük yol gösterme ve yardımlarla başarılı olduğu tespit edilmiştir. Ayrıca araştırmaya katılan deney grubu öğrencilerinin \%9.5'inin parça-bütün ilişkisini gerçekleştiremediği belirlenmiştir. Öğrencilerin büyük bir kısmının (\%90.4) öğrencilerden beklenilen düzeyde başarılı oldukları ve sayılar arasında parça-bütün ilişkisi kurarken sayıları farklı şekillerde ifade edebildikleri de yapılan incelemelerden görülmüştür. Görüşme esnasında öğrenciler, 23 sayısını "22+1, 21+2..." olarak ifade edebilmektedirler. Bu ilişkiyi bilmelerinden dolayı zihinden toplama (36+13) işlemi yaparken bir öğrenci 36 sayısını en yakın onluğa yuvarlayabilmek için 13 sayısını "9+4" olarak parçalayabilmektedirler. Ayrıca, başka bir öğrenciden"28+15" sayısını zihinden toplayarak yapması istenmiş ve bu öğrenci sonucu "28-3=25" olarak bulmuştur. Ardından da, 25 sayısını 20 ve 5 olarak parça-bütün ilişkisini kurarak ayırmıştır. Sonrasında ise, 15 sayısını 10 ve 5 olarak ayırmıs, 20 ile 10 'u toplamış, parçaya ayrılan 5 ile 5'i toplamış ve "30+10" işlemini yapıp çıkarmış olduğu 3 sayısını da eklemiştir. İşlemlerin sonucunda, toplamı 43 olarak bulmuştur. Bu şekilde, bir öğrencinin parça-bütün ilişkisini kurabilmesi de ona yaptığı işlemlerde esneklik elde etmesini sağlamaktadır.

Birlik ve Onlukları Ayrı Ayrı Toplayabilme: Öğrencilerin ilkokul birinci sınıftan itibaren en fazla üzerinde durdukları hatta tek yöntem olan onluk ve birlik ayırma, zihinden toplama işlemlerinde de etkisini göstermektedir. $\mathrm{Bu}$ yöntem üzerinde daha çok durmalarından dolayı öğrenciler kendilerine yöneltilen sorularda (bu işlemler ister "30+20" şeklinde onun katlarını toplama olsun, isterse "27+13" gibi toplamı elliyi geçmeyen sayı olsun) genellikle onluk-birlik ayrıma yöntemini tercih etmektedirler. Yapılan uygulamalarda öğrencilere ZTT'nda diğer yöntemlerin de yapılışı gösterilmiş fakat öğrenciler bu yöntemi yaptıkları işlemlerde tercih etmemişlerdir. Bu çalışmada da, öğrencilerin \%85.8'inin herhangi bir yardım ya da destek olmaksızın oldukça başarılı, \%14.28'inin ise küçük yol gösterme ve yardımlarla başarılı olduğu tespit edilmiştir.

İleriye ve Geriye Onar Onar Sayma: Bu çalışmada, öğrencilerin onar onar ileri-geri saymada, \%76.2'sinin herhangi bir yardım ya da destek olmaksızın 
oldukça başarılı, \%23.8'inin küçük yol gösterme ve yardımlarla başarılı olduğu belirlenmiştir. Bu yöntemin öğrencilerin onluk ve birlik ayırmadan sonra en çok tercih ettikleri yöntem olduğu da yapılan görüşmelerde ortaya çıkmıştır. Öğrencilerden ZTT üzerinde üzerine onar sayarak soruları cevaplamaları istenildiğinde, öğrencilerin bu yöntemi daha kolay uyguladığı görülmüştür. Bu yöntemi ZTT'de uyguladıktan sonra, öğrencilerin yönlendirme yapmadan sorulan diğer işlemlerde onar onar sayma yöntemini tercih ettikleri de görülmüştür.

\section{Tartışma, Sonuç ve Öneriler}

Yapılan bu çalışma ile ASSURE ÖTM ile planlanan bir dersin, ilkokul ikinci sınıf öğrencilerinin zihinden toplama işlemi konusundaki başarı durumlarına etkisinin incelenmesi amaçlanmıştır. Bu amaç ile hazırlanan çalışmanın birinci problem soru ile ilkokul ikinci sınıfta ASSURE ÖTM aracılı̆̆ ile geliştirilen ders planının, öğrencilerin "Zihinden Toplama İşlemi" ndeki başarıları açsından deney grubu ile kontrol grubu arasında istatistiksel olarak başarı durumlarına bakılmıştır. Araştırmaya katılan iki gruba da uygulanan son testten elde edilen bulgulardan, ASSURE ÖTM'nin uygulandığ1 deney grubunun, öğretmenleri ile derslerini sürdürmekte olan kontrol grubuna kıyasla önemli düzeyde zihinden toplama işlemi yapma başarısının arttığı anlaşımaktadır. Ayrıca zihinden işlemleri çözmede kullandıkları adımlar, öğrencilerle yapılan görüşmeler esnasında öğrencilerin ZTT programı kullanmaktan keyif aldığı gözlemlenmiştir. Aynı zamanda, öğrencilerin zihinden toplama işlemlerini yaparken ZTT programını kullanarak sayılar arasındaki ilişkileri daha iyi gördükleri de belirlenmiştir. Deney ve Kontrol grubuna uygulanan ön test ve son test bulgularına göre ASSURE ÖTM ile hazırlanan bir ders planın etkili olduğu sonucuna ulaşılmıştır. Bu araştırma kapsamında elde edilen bu sonuç da, yapılan diğer araştırmalarda (Baran, 2010; Eren, Aktürk, Demirer ve Şahin, 2010; Özdemir ve Uyangör, 2011; Göksu, Özcan, Çakır ve Göktaş, 2014; Karakış, 2014; Çetinkaya ve Taş, 2016; Karaduman, Memnun ve Çakır. 2019; Gündüzalp ve Yıldız 2020) olduğu gibi benzer bir şekilde ASSURE ÖTM'nin etkililiğini göstermektedir.

Çalışmanın ikinci problem sorusunda ise ilkokul ikinci sınıfta ASSURE ÖTM aracılığı ile planlanan bir derste, öğrencilerin "Zihinden Toplama İş- 
lemi" faktörleri (Onluk ve birliklere ayırma, parça-bütün ilişkisi kurma, sayıları en yakın onluğa yuvarlayabilme, üzerine sayma yapma) açısından istatistiksel olarak anlamlı düzeyde bir ilişki olduğunu göstermiştir. ASSURE ÖTM ile planlanan derste öğrencilerin en yakın onluğa yuvarlayabilme kazanımına yönelik yapılan başarı testinde tüm öğrencilerin başarılı olduğu, öğrencilerin görüşme sonuçlarına göre \%95'inin başarılı ve çok başarılı olduğu görülmüştür. Hem görüşme hem de başarı testi sonuçlarına göre öğrencilerin parça bütün ilişkisi kurmada $\% 90^{\prime} 1$, onluk ve birlikleri ayırma, ileri ve geri onar onar saymalarına bakıldığında öğrencilerin tamamının başarılı ve çok başarılı olduğu görülmüştür. Kabaran ve Tertemiz (2019)'in araştırmasında da öğrencilerin öncelik olarak (öğrencilerin tamamı) birlik ve onlukları ayırarak toplama işlemini tercih ettikleri görülmektedir. Ayrıca Duran, Doruk ve Kaplan (2016) araştırmasında altıncı sınıf öğrencilerin en fazla onluk ve birlikleri ayırarak zihinden toplama işlemini tercih görülmüştür. Bunun sebebi ise ya bir önceki sınıftan itibaren öğrencilerin toplama işlemi alışkanlıkları ya zihne en kolay gelen bir yöntem olması ile açıklanabilir.

Üçüncü araştırma sorusu ile ilkokul ikinci sınıfta ASSURE Öğretim Tasarım Modeli aracıllğı ile planlanan derste, öğrencilerin zihinden toplama işlemine ait kazanımları gerçekleştirebilmeleri açısından oluşturdukları farklılıklar belirlenmeye çalışılmıştır. Öğrenciler ile yapılan görüşmeler esnasında, ASSURE ÖTM ile planlanan derste öğrencilerin tercih ettiği yöntemlere, bilgisayar programlarının etkililiğine ve öğrenme farklarına bakılmıştır. Başarı testi ve görüşmelerde elde edilen bulgulara göre öğrenciler öncelik olarak onluk ve birlik ayırma yöntemini tercih etmişlerdir. "Bu soruyu başka nasıl çözebilirsin?" sorusu yöneltildiğinde ise öğrencilerin en yakın onluğa yuvarlayarak sonuca ulaştığı görülmüştür. Öğrencilerden aynı toplama işlemini farklı bir yolla çözmeleri istenildiğinde üzerine onar onar saymayı tercih etmişlerdir. Aynı zamanda parça-bütün ilişkisini kurabildikleri ancak işlem içinde ilk önce bunu kullanmayı tercih etmedikleri görülmüştür. Öğrencilerin tamamına yakını parça-bütün ilişkisi kurabilse de sadece iki öğrencinin ilk önce parça-bütün ilişkisi kurduğu görülmüştür. Görüşme esnasında öğrenciler, yöneltilen sorularda zihinden toplama işlemi yöntemlerini kullanmada zorluk yaşadıklarında bilgisayar programından faydalanmışlardır. Öğrenciler bilgisayar programı yardımı ile sonuca ulaşabilmiştir. Bu araştırma sorusu neticesinde yapılan her bir işlemin zihnimizde belli bir aşamaya 
göre gerçekleştiği ve her bir öğrencide benzerliklerin olmasına rağmen bu sürecin farklı işlediği görülmüştür. Zihnimiz alışkanlık kazanarak bir anda yapabiliyor gibi görünse de aslında zihnimizde çizilen haritanın aşamaları ile sonuca gidildiği görülmüştür. Aynı zamanda öğrencilerin hangi yolları kullanması gerekeceğini bilmesi, onların işlem esnekliği konusundaki yetkinliklerini ortaya çıkartmaktadır.

ASSURE Öğretim Tasarım Modeli ile planlanan bir öğretim tasarımının ilkokul ikinci sınıf öğrencilerinin zihinden toplama işlemleri konusundaki başarı durumlarına etkisinin incelenmesi amacıyla gerçekleştirilen bu çalışmada, öğrencilerin başarılı olduğu sonucuna ulaşılmıştır. ASSURE Öğretim Tasarım Modeli ile planlanan bir derste öğrencilerin bireysel özelliklerine uygun olarak, istenilen hedeflere ulaşmada etkili olduğu sonucuna varılmıştır. Bu sonuç ile öğrencilerin arasındaki bireysel farklılıklardan kaynaklanan öğrenme sorunlarının teknolojinin öğretime dâhil olması ile öğretim daha etkili olmuştur.

Araştırmanın bulguları çerçevesinde ASSURE Öğretim Tasarım Modeli ile ilgili olarak araştırmacılara aşağıdaki önerilerde bulunulmuştur.

- Uygulamanın yapıldığı sınıfta Tablo 1'deki öğrenci analizinde de görüldüğü üzere bireysel farklılıkların çok olmadığı bir grupta çalışma yapılmiştır. Bu sebeple araştırmacılar bireysel öğrenme farklılıklarının olduğu bir sinffta benzer bir uygulamayı çalışabilir.

- ASSURE Öğretim Tasarım Modeli Erken çocukluk dönemi ile ilgili yapılan çalışmalarda kullanılabilir, böylelikle öğrencilerin öğrenme çıtıları hakkında bilgi elde edilebilir.

- ASSURE Öğretim Tasarım Modeli ile tasarlanan materyalin farklı sınıflardaki öğrenme başarısına etkisine bakılabilir. 


\title{
EXTENDED ABSTRACT
}

\section{The Effect of The Course Design Based on Assure Instructional Design Model on Success in Mental Addition in the Second Grade}

\author{
Ali Çibir - Yeliz Yazgan \\ Bursa Uludă̆ University
}

The Ministry of National Education (2018) aims to enable students to be mathematically literate and use what they learn in daily life in the mathematics course curriculum. In order for this to happen, it is expected that students will be able to use estimation and mental addition processes effectively. Even if we have not received any school education, from shopping to our other daily operations, we reach the result by using mental calculation skills (Çekirdekçi, 2005). When using mental calculation and estimation, different or partially dependent strategies are developed from formal education without using a calculator or computer (Çavuş Erdem ve Duran, 2005). Students need to be able to make learning a part of their life and explore learning through their experiences in order to structure their own learning (Karakış, 2014). The teacher should be able to design learning in order to organize the learning environment of the students in this process (Yiğit, 2007). While designing this learning, ASSURE Instructional Design Model (IDM), which is more suitable for a lesson plan, can be used. Education programs prepared with ASSURE IDM are more effective, efficient and attractive for students to reach desired goals. Thus, high-level learning can be achieved with the active participation of students by using the most appropriate media and materials in order to achieve the desired learning goals, taking into account the individual characteristics of the students (Uysal ve Gürcan, 2004). It is observed that the studies on ASSURE IDM concentrate on Mathematics and Science courses and are generally supported by technology-supported teaching models. In this study, it was aimed to examine the effect of the instructional design developed for the objective of "Adding from the mind" to the second grade mathematics lesson with ASSURE IDM and a technology 
supported program. In this study, the convergent parallel design in which qualitative and quantitative data are used together was used. In this study, the study was carried out in "Experimental Design with Pre-Post Test Control Group" in order to obtain quantitative data. Quantitative data were obtained by applying an achievement test consisting of 10 questions, which was developed by the first researcher, as a pre-test and a post-test to the experimental and control groups. Qualitative data were obtained from the interviews with the students in the experimental group by the first researcher. In the interviews with the students in the experimental group, the mental addition skills of the students were examined. In this interview, a total of seven questions were asked.

The study groups within the scope of the research are composed of second grade students studying in two different classes of a primary school in the central district of Kütahya in the first semester of the 2019-2020 academic year. Of these, 21 students in the 2-D class were included in the study as the experimental group and 20 students in the 2-B class studying at the same school were included in the study as the control group. In the analysis of research data obtained from student groups, besides descriptive statistics (frequency, percentage and arithmetic mean values), Mann Whitney U-Test was used for paired comparisons between groups.

From the findings obtained from the last test applied to both groups participating in the study, it is understood that the success of the experimental group to which the ASSURE IDM was applied increased significantly compared to the control group. It showed that a lesson planned through ASSURE IDM in the second grade of primary school created a statistically significant difference in students in terms of "Mental Additon" factors (separating tens and units, establishing a piece-whole relationship, rounding the numbers to the nearest tens, counting on them). According to the findings obtained from the achievement test and interviews, the students preferred the ten and one separation method as a priority. When asked "How else can you solve this question?" it was seen that the students reached the result by rounding to the nearest ten. When the students were asked to solve the same addition in a different way, they preferred to count tens on top. At the same time, it has been observed that they can establish the piece-whole relationship but do not prefer to use it first in the process. The fact that they prefer collecting by separating tens and units 
as their priority is similar to other studies (Kabaran and Tertemiz, 2019; Doruk and Kaplan, 2016). In addition, the results of this study overlap with the results of other studies showing the effectiveness of ASSURE IDM (Baran, 2010; Eren, Aktürk, Demirer, and Şahin, 2010; Özdemir and Uyangör, 2011; Göksu, Özcan, Çakır and Göktaş, 2014; Karakış, 2014; Çetinkaya and Taş, 2016; Karaduman, Memnun and Çakır.2019; Gündüzalp and Yıldiz 2020).

\section{Kaynakça / References}

Akay, Y. (2017). Ilkokul 4.Sınıf matematik dersinde oluşturulan öğretim tasarımına dayalı uygulamalarm etkililiğ̈i (Yayımlanmamış Doktora Tezi). Balıkesir Üniversitesi, Sosyal Bilimler Enstitüsü, Balıkesir.

Alkan, V., Şimşek, S. ve Armağan Erbil, B. (2019). Karma yöntem deseni: Öyküleyici alanyazın incelemesi. Eğitimde Nitel Araştırma Dergisi, 7(2), 558-581.

Ateş, M. (2017). Yapılandırmacı 7E modeline göre düzenlenmiş öğretim etkinliklerinin Türkçe dersindeki başarıya ve öğrenmedeki kalıcllığa etkisi. Erzincan Üniversitesi Eğitim Fakültesi Dergisi, 19(2), 335-346.

Baran, B. (2010). Experiences from the process of designing lessons with interactive whiteboard: Assure as a road map. Contemporary Educational Technology, 1(4), 367-380.

Bayezit, B. (2019). Ortaokul 6. sinıf hacim konusunun öğretiminde teknoloji entegrasyonuna yönelik bir öğretim tasarımının geliştirilmesi (Yüksek Lisans Tezi). Balıkesir Üniversitesi, Fen Bilimleri Enstitüsü, Balıkesir.

Buttler S. (2019). Teaching Math Every Day. 21.11.2019 tarihinde http://www.earlychildhoodnews.com/earlychildhood/article view.aspx?ArticleID=229 adresinden erişildi.

Büyüköztürk, Ş. (2015). Sosyal bilimler için veri analizi el kitabı. Ankara: Pegem Akademi.

Camnalbur, M. (2008). Bilgisayar destekli öğretimin etkililiği üzerine bir meta analiz çalışması. (Yüksek Lisans Tezi). Marmara Üniversitesi, Eğitim Bilimleri Enstitüsü, İstanbul.

Creswell, J. W. ve Plano, Clark. V. L. (2020). Karma yöntem araştırmaları: Tasarımı ve yürütülmesi (Çev. Dede ve S. B. Demir s.85). Ankara: Anı Yayıncilik. 
Çavuş Erdem, Z. ve Duran, H.(2015). Yetişkinlerin zihinden hesaplama becerilerinin özellikleri üzerine karşılaştırmalı bir çalışma. Türk Bilgisayar ve Matematik Dergisi, 6(3), 463-482.

Çekirdekçi, S. (2015). Illkokul 4. sınıf öğrencileri için sayı hissi testinin geliştirilerek öğrencilerin sayı hislerinin incelenmesi (Doktora Tezi). Marmara Üniversitesi, Eğitim Bilimleri Enstitüsü.

Çetin, H. ve Öztürk, Ş. (2020). İlkokul matematik öğretim programının sayı duyusu temel bileşenlerine göre incelenmesi. Ulusal Ĕ̆itim Akademisi Dergisi, 4(2), 163-180.

Çetinkaya, M. ve Taş, E. (2016). Web destekli ve etkinlik temelli ölçme değerlendirme materyali geliştirilmesi. Ĕ̆itim ve Öğretim Araştırmaları Dergisi, 5(1), 21-28.

Duran, M., Doruk, M. ve Kaplan, A. (2016). Ortaokul Öğrencilerinin zihindhesaplama yaparken kullandıkları stratejiler. İlköğretim Online, 15(3), 742-760.

Esmer, E. (2018). Öğretim tasarımında bir model: Dick and Carey ve Carey. Trakya Üniversitesi Eğitim Fakültesi Dergisi, 8(2), 274-284.

Eren, F., Aktürk, A.O, Demirer, F. ve Şahin, İ. (2010). Bilişim teknolojileri dersinde ASSURE modeline göre hazırlanmış ders materyalinin akademik başarı ve derse karşı tutum ve bilgisayar öz yeterliliğine etkisi. International Computer and Instructional Technologies Symposium Proceedings kitabı içerisinde, Konya.

Fidan, N. ve Duman, T. (2014). Sınıf öğretmenlerinin yapılandırmacı yaklaşımin gerektirdiği niteliklere sahip olma düzeyleri. Eğitim ve Bilim, 39(174), 143-159.

Göksu, İ., Özcan, K.V., Çakır R. ve Göktaş, Y. (2014). Türkiye'de öğretim tasarımı modelleriyle ilgili yapılmış çalışmalar. Illköğretim Online, 13(2), 694-709.

Gündüzalp, C. ve Yıldız, E.P. (2020). ASSURE modeli ile tasarlanmış bir dersin öğrencilerin bilgi iletişim teknolojileri kullanımına yönelik tutum ve bilgisayar kaygı düzeylerine etkisi. Ekev Akademi Dergisi, 24(83), 107-137.

Kabaran, H. ve Tertemiz, N. (2018). İlkokul ikinci sınıf öğrencilerinin doğal sayılarla toplama ve çıkarma işlemi gerektiren esnek problem çözümlerinin incelenmesi. İlköğretim Online, 18(4), 1837-1857. 
Karakış, H. (2014). Illköğretim 4. sımıf "kesirler" ünitesi için geliştirilen bilgisayar destekli etkinliklerin öğrenci başarı ve tutumuna etkisi. (Yüksek Lisans Tezi). Balıkesir Üniversitesi, Fen Bilimleri Enstitüsü, Balıkesir.

Karaduman, B., Sezgin Memnun, D. ve Çakır, C. (2019). ASSURE Öğretim Tasarım Modeli ile olasılık kavramının öğretimine yönelik bir öneri. Uluslararası Bilimsel Araştırmalar Dergisi (IBAD), PROCEEDINGS ICES-2019, 456-468.

Keleş, E., Fiş-Erümit, S., Özkale, A. ve Aksoy, N. (2016). Öğretim tasarımcıları için bir yol haritası: Öğretim tasarım modellerinin karşılaştırılması. Ankara Üniversitesi Eğitim Bilimleri Fakültesi Dergisi, 49(1), 105-139.

Lubinsk, C.A. and Otto, A.D. (1997). Literature ande algebraic reasoning. In, D. Thiessen (Ed.), Exploring Estimation Through Children's Literature (p.81-90). the United States of America.

MEB (2005). Ilköğretim Okulu Matematik Dersi (1-5. sinıflar) Öğretim Programı. Ankara: MEB Yayınları.

MEB (2018). İlköğretim Okulu Matematik Dersi (1-8. Simıflar) Öğretim Programı. Ankara: MEB Yayınları.

Ocak, M.A. (2015). Öğretim tasarımı: Kuram, modeller ve uygulamalar. Ankara: Anı Yayıncilik.

Olkun, S., Altun, A., Göçer Şahin, S. ve Akkurt Denizli, Z. (2015). Temel sayı yeterliliklerindeki eksiklikler ilköğretim öğrencilerinde düşük matematik başarısına neden olabilir. Eğitim ve Bilim, 40(177), 141-159.

Özdemir, E. ve Uyangör, S. (2011) Matematik eğitimi için bir öğretim tasarımı modeli.e-Journal of New World Sciences Academy, 6(2), 1786-1796.

Öztürk, N. (2017). Fen Öğretiminde 5E/7E öğrenme modelleri. H. G. Hastürk (Edt.), Teoriden Pratiğe Fen Bilimleri Öğretimi kitabı içerisinde. Ankara: Pegem Akademi.

Şentürk, C. (2010). Yapılandırmacı yaklaşım ve 5E öğrenme döngüsü modeli. Eğitime Bakış, 6(17), 58-61.

Uysal, Ö. ve Gürcan, A. (2004). ASSURE Modeli ile öğretim tasarımı ve örnek bir uygulama. XIII. Ulusal Eğitim Bilimleri Kurultayi'nda sunulmuş bildiri, Malatya.

Van de Walle, J., Karp, K.S. ve Bay-Williams, J.M. (2016). Ilkokul ve ortaokul matematiği: Gelişimsel yaklaşımla öğretim (S. Durmuş, Çev. Ed.). Ankara: Nobel Yayıncilı.

Yazgan, Y., Bintaş, J. ve Altun, M. (2002). İlköğretim 5. sınıf öğrencilerinin zihinden hesap ve tahmin becerilerinin geliştirilmesi. 5. Ulusal Fen 
Bilimleri ve Matematik Eğitimi Kongresi, 17.09.2016 tarihinde http://www.old.fedu.metu.edu.tr/ufbmek-5/b_kitabi/PDF/Matematik/Bildiri/ t259 d.pdf adresinden erişildi.

Yıldırım, A. ve Şimşek, H. (2013). Sosyal bilimlerde nitel araştırma yöntemleri. Ankara: Seçkin Yayıncllık.

Yiğit, A. (2007). İlköğretim 2.sını seviyesinde bilgisayar destekli eğitici matematik oyunlarının başarıya ve kalıılığa etkisi (Yüksek Lisans Tezi). Çukurova Üniversitesi, Sosyal Bilimleri Enstitüsü, Adana.

Whitin, D.J. (1994). Exploring Estimation Through Children's Literature. T., Diane (Edt), Exploring mathematics through literature articles and lessons for prekindergarten through grade 8. içinde (s.21-28). United States of America.

\section{Kaynakça Bilgisi / Citation Information}

Çibir, A. ve Yazgan, Y. (2021). ASSURE öğretim tasarım modeline dayalı ders tasarımının ilkokul ikinci sınıfta zihinden toplama işlemindeki başarıya etkisi. OPUS-Uluslararası Toplum Araştırmaları Dergisi, 18(39), 485-520. DOI: 10.26466/opus.846504 